\title{
PIRAMIDALNE STRUKTURE I DRUŠTVA S UZAJAMNIM UDJELIMA KAO OBLIK ODSTUPANJA OD NAČELA „JEDNA DIONICA - JEDAN GLAS“
}

Doc. dr. sc. Antonija Zubović*

Prof. dr. sc. Edita Čulinović-Herc**
UDK: 347.72 .034

https://doi.org/10.30925/zpfsr.40.1.4

Ur.: 28. siječnja 2019.

Pr.: 25. veljače 2019.

Izvorni znanstveni rad

\section{Sažetak}

U dioničkim društvima se ponekad koriste dionice koje daju nejednako pravo glasa, piramidalnestrukture idrugimehanizmijačanja kontrole, kojipredstavljaju odstupanje od načela proporcionalnosti. Uspostavljeni mehanizmi za jačanje i/ili zadržavanje kontrole, u čemu prednjači uporaba piramidalnih struktura relevantni su za situacije u kojima nad uvrštenim društvom dolazi do promjene kontrole (preuzimanje). U radu se nakon izlaganja taksonomije mehanizama za povećanje kontrole, posebna pozornost usmjerava na ona odstupanja od načela proporcionalnosti koja su nastala na tržištu kapitala, a to su piramidalne strukture i društva s uzajamnim udjelima. Prije njihove analize, ispituju se njihovi učinci na ponašanje unutarnjih dionika korporativnog upravljanja u uvrštenim društvima, do kojih dolazi pri dobrovoljnom i neprijateljskom preuzimanju, ali i u scenariju kada preuzimanja nema, vodeći pritom računa radi li se o društvu s disperziranom ili koncentriranom dioničarskom strukturom. Također se iznose i analiziraju empirijski pokazatelji instrumenata za pojačanje kontrole u pojedinim europskim državama. U posljednjem dijelu rada posebno se analiziraju metode izračunavanja glasačke snage kod piramidalnih struktura i društva s uzajamnim udjelima, nakon čega se iznose zaključna razmatranja.

Ključne riječi: piramidalne strukture; društva s uzajamnim udjelima; odstupanje od načela proporcionalnosti; uvrštena dionička društva.

* Dr. sc. Antonija Zubović, docentica, Sveučilište u Rijeci, Pravni fakultet; azubovic@pravri.hr.

** Dr. sc. Edita Čulinović-Herc, redovita profesorica u trajnom zvanju, Sveučilište u Rijeci, Pravni fakultet; edita@pravri.hr.

Ovaj rad je financiralo Sveučilište u Rijeci projektom Pravni aspekti restruktuiranja trgovačkih društava i tranzicija prema novoj kulturi korporativnog upravljanja (uniri-drustv-18-43). 


\section{UVOD}

U dioničkim društvima, uobičajeno postoji većinski dioničar ili dioničar koji nad društvom ima kontrolu. Najčešće se radi o tomu da taj položaj zauzima neka osoba ili obitelj, ${ }^{1}$ ali kontrola može biti i u rukama države. To društvo ima koncentriranu dioničarsku strukturu, za razliku od disperzirane, kojoj je svojstveno da u društvu ne postoji dominantan dioničar. Opće je poznata činjenica da je prvi oblik držanja dionica, (odnosno udjela) karakterističan za kontinentalnu Europu, ${ }^{2}$ države Latinske Amerike i Azije, ${ }^{3}$ dok je drugi više prisutan u trgovačkim društvima anglosaksonskoga kruga. ${ }^{4}$ No, čak i kada se radi o uvrštenim društvima kojima je svojstvena disperziranija struktura s obzirom na to da se određenim blokom dionica slobodno trži (engl. free float) vrlo su često i ta društva pod kontrolom obitelji. ${ }^{5}$

U pravu društava, posebno u dijelu koji se bavi financijskim korporativnim pravom, niz je autora istraživalo na koji način korištenje jednog ili drugog modela dioničarstva (koncentriranog ili disperziranog) utječe na stil upravljanja društvom, način donošenja odluka u društvu te upravljanje sukobima interesa. ${ }^{6}$ Polazi se od toga

1 Članovi obitelji mogu biti zastupljeni kao dioničari, imati položaj člana uprave, odnosno drugih organa društva, odnosno na druge načine biti uključeni u korporativno upravljanje društvom. Vidi opširnije Uhlaner, L. M., Family Business and Corporate Governance, u: Wright, M., Siegel, D. Keasey., Filatochev, I. The Oxford Handbook of Corporate Governance, OUP, 2013., str. 389. U ovom radu se razmatra samo sudjelovanje "obitelji" u korporativnoj strukturi.

2 Vidi analizu uzorka piramidalnih struktura u Poljskoj na primjeru društava uvrštenih na varšavsku burzu. Aluchna, M., Kuszewski, T., Pyramidal structures: The evidence from Poland, South African Journal of Business Management, vol 49, 1/2018., dostupno na: https://sajbm. org/index.php/sajbm/article/view/1/802 (posjećeno 10. 1. 2019). U radu je analiziran uzorak 168 nefinancijskih uvrštenih društava na varšavskoj burzi od 2010. do 2014. Autori su zaključili da su piramidalne strukture korištene kao sredstvo za ekspanziju poslovne grupe u uvjetima gdje su resursi vanjskog kapitala vrlo skupi.

3 Morck, R., A history of corporate governance around the world: Family business groups to professional managers, University of Chicago Press, 2005., Morck, R., The riddle of the great pyramids, u: Colpan, A. M., Hikino, T., Lincoln, J.R. (eds.), The Oxford Handbook of Business Groups, 2009., str. 602-628.

4 Villalonga, B., Amit, R. H., How are U.S. Family Firms Controlled? (July 1, 2007). European Corporate Governance Institute (ECGI) - Finance Working Paper No. 131/2006, dostupno na: https://ssrn.com/abstract=891004 (posjećeno 10. 1. 2019.)

5 Uhlaner, L. M., op. cit., str. 390. Autorica citira jednu kanadsku studiju prema kojoj je na uzorku od 1200 kanadskih uvrštenih društava utvrđeno da je više od polovice pod kontrolom obitelji. Vidi studiju kod Gadhoum, Y., Power of Ultimate Controlling Owners: a Survey of Canadian Landscape, Journal of Management Governance, 10, 2006, str. 179-204. Ginglinger, E., Hamon, J., Ownership, Control and Market Liquidity (June 1, 2012). Finance, 2012, 33, 2, str. 61-99. Dostupno na https://ssrn.com/abstract=2097795, str. 10., iznose podatak da je u Francuskoj 64,82 \% uvrštenih društava pod kontrolom obitelji. Masulis, R. W., Pham, P. K., Zein, J., Family Business Groups around the World: Financing Advantages, Control Motivations and Organizational Choices (April 21, 2011). Review of Financial Studies, Forthcoming; ECGI Finance Working Paper No. 240/2009. Dostupno na: https://ssrn.com/abstract=1363878, str. 3., koristeći uzorak od 28.635 društava u 45 država iznose podatak da je $19 \%$ uvrštenih društava pod kontrolom obitelji. Dalje ističu da na pojedinim tržištima taj postotak doseže i do $40 \%$ (posjećeno 10.1.2019).

6 Aluchna, M., Kuszewski, T., op. cit., str. 1; Castañer, X., Kavadis, N., Does good corporate 
da dioničari, ovisno o tomu radi li se o društvu kojem je svojstvena koncentrirana, odnosno disperzirana struktura, imaju različite investicijske ciljeve pri ulaganju u društvo (npr. dugoročni ili kratkoročni investicijski horizont). Ti njihovi ciljevi utječu na njihovo ponašanje pri oblikovanju investicijskih strategija unutar društva, ${ }^{7}$ ili revidiranja strateških ciljeva društva, ${ }^{8}$ politiku upravljanja dobiti ${ }^{9}$ i sl.

Tako autori navode da u društvima disperzirane dioničarske strukture, odnosno društvima gdje ne postoji dominantni dioničar, postoji intenzivna napetost između članova uprave i dioničara. ${ }^{10}$ Dioničari tih društava uobičajeno su usmjereni na maksimizaciju dobiti i isplatu dividende te su spremni ,izaći iz tog ulaganja“, ako ono nije ispunilo njihova investicijska očekivanja. Manje su skloni reinvestiranju dobiti, primjerice u razvoj i istraživanje $\mathrm{i}$ operativne djelatnosti, za razliku od većinskih dioničara u društvima koja imaju koncentriranu dioničarsku strukturu, čiji je vremenski horizont ulaganja u pravilu dulji. ${ }^{11}$ Štoviše, kada je u pitanju društvo s koncentriranom dioničarskom strukturom, njegovi većinski dioničari, odnosno dioničari koji imaju kontrolu, ne samo da nastoje ostvariti, odnosno (trajno) zadržati kontrolu nad tim društvom putem držanja većinskog ili kontrolnog bloka dionica, već uvode i dodatne mehanizme kojima nastoje ojačati tu kontrolu, a koji se jednim imenom nazivaju odstupanja od načela proporcionalnosti. Također se za te mehanizme rabi izraz prekomjerna kontrolna prava (engl. excess control rights), koja se susreću i kod uvrštenih društava koja se nalaze, primjerice pod kontrolom obitelji. ${ }^{12}$

governance prevent bad strategies? An empirical analysis of non-value creating financial diversification in French companies, 2000-2006, Strategic Management Journal, vol. 34, 7/2013, str. 863-876; Combs, J., Commentary: The servant, the parasite, and the enigma: A tale of three ownership structures and their affiliate directors, Entrepreneurship Theory and Practice, vol. 32, 6/2008, str. 1027-1033; Van Essen, M., Carney, M., Gedajlovic, E., Heugens, P., How does family control influence firm strategy and performance? A meta-analysis of US publicly listed firms, Corporate Governance: An International Review, vol. 23, 1/2015, str. 3-24; Van Essen, M., Heugens, P., Van Oosterhout, H., Otten, J., An institution-based view of executive compensation: A multilevel meta-analytic test, Journal of International Business Studies, vol. 43, 3/2012, str. 396-423; Shleifer, A., Vishny, R., A survey of corporate governance, Journal of Finance, vol. 52, 2/1997, str. 737-783; Carlin, W., Mayer, C., Finance, investment and growth, Journal of Financial Economics, vol. 69, 1/2003, str. 191-226; Franks, Julian R., Mayer, Colin, Ownership and Control of German Corporations (July 2001). CEPR Discussion Paper No. 2898, dostupno na: https://ssrn.com/abstract=279387 (posjećeno 10. 1. 2019.).

7 Castañer, X., Kavadis, N., op. cit., str. 863-876; Combs, J., op. cit., str. 1027-1033; Van Essen et al., op. cit., str. 3-24.

8 Castañer, X., Kavadis, N., op. cit., str. 863-876; Van Essen et al., op. cit., str. 3-24.

9 Shleifer, A., Vishny, R., op. cit., str. 737-783.

10 Loc. cit.

11 Carlin, W., Mayer, C., op. cit., str. 191-226.

12 Uhlaner, L. M., op. cit., str. 390. Autori Shyu i Lee objašnjavaju kako pojačana prava većinskog dioničara ostvaruju na uštrb manjinskih dioničara, stavljajući naglasak na utjecaj na kontrolu novčanih tijekova. Vidi Shyu, Y.-W., Lee. C.I,, Excess Control Rights and Debt Maturity Structure in Family-Controlled Firms, Corporate Governance, An International Review, vol. 17, 5/2009, str. 611-628. https://onlinelibrary.wiley.com/doi/abs/10.1111/j.14678683.2009.00755.x (posjećeno 10. 1. 2019.) Vidi još Michiels, A., Vincent, M., Financing Decisions in Family Businesses: A Review and Suggestions for Developing the Field, Family Business Review, vol. 30, 4/ 2017, str. 369-399. https:/journals.sagepub.com/doi/ 
Uspostavljeni mehanizmi za jačanje kontrole dolaze posebno do izražaja u postupcima preuzimanja tih (uvrštenih) društava, bilo da se preuzimanje odvija kao prijateljsko ili „neprijateljsko“ (engl. hostile takeover). Ako je riječ o prijateljskom preuzimanju, mehanizmi odstupanja od načela proporcionalnosti utječu na ponašanje ponuditelja na sljedeći način. Ponuditelj će varirati iznos ponuđen u ponudi za preuzimanje, ovisno o tomu na koji način su u njoj kalibrirana (glasačka) prava u dionicama koje su predmet ponude, a svako sniženje ili povišenje ponuđene cijene otkupa dionice izravno će utjecati na njegov ukupni trošak preuzimanja ciljnog društva. Ako se radi o ponudi za preuzimanje koja dolazi od neprijateljskog ponuditelja, tada većinski dioničar koji je već primjenom navedenih mehanizama ojačao svoju glasačku poziciju, otežava preuzimanje neprijateljskom ponuditelju pa taj mehanizam jačanja kontrole ima funkciju i protupreuzimateljske mjere. Kako su pri preuzimanju društva u posebno osjetljivom položaju članovi uprave koji s promjenom kontrole mogu očekivati prestanak mandata, uprava ciljnog društva uobičajeno je više usredotočena na zaštitu svog položaja, nego na širu sliku dobrobiti društva. Osim na upravu, mehanizmi odstupanja od načela proporcionalnosti također utječu na ponašanje dioničara pri preuzimanju koji nastoje pri „,izlasku“ ostvariti što je moguće veću cijenu (engl. takeover premium).

No, i u situacijama kada društvo nije predmet preuzimanja, odstupanja od načela proporcionalnosti mijenjaju ponašanje svih unutarnjih dionika korporativnog upravljanja - većinskog dioničara, manjinskih dioničara i članova uprave, što posebice dolazi do izražaja u društvima koncentrirane korporativne strukture, a neki od tih mehanizama mogu biti i de facto, odnosno funkcionalne mjere obrane od preuzimanja. $^{13}$

Prije nego što se u ovom radu usustave odstupanja od načela proporcionalnosti prema usvojenoj taksonomiji, potrebno je podsjetiti se što zapravo znači načelo proporcionalnosti. To načelo koje se još naziva i načelo ,jedna dionica - jedan glas“ (engl. one share-one vote) polazi od toga da dioničarima koji drže jednaki udio u temeljnom kapitalu društva treba dati jednako pravo glasa i time im omogućiti jednaki utjecaj na donošenje ključnih odluka u društvu. Još je Visoka skupina stručnjaka za pravo društava u izvješću podnesenom 2002. godine ${ }^{14}$ inzistirala na primjeni načela proporcionalnosti u postupku preuzimanja pri donošenju odluke o primjeni protupreuzimateljske mjere. Međutim, zbog protivljenja država članica stavljenom prijedlogu, u usvojenom tekstu Direktive o ponudama za preuzimanje, kod

abs/10.1177/0894486517736958?journalCode=fbra. (posjećeno 10. 1. 2019.) Villalonga, B., Amit, R., How Do Family Ownership, Control and Management Affect Firm Value? Journal of Financial Economics, vol. 80, 2/2006, str. 385-417. Ehrhardt, O., Nowak, E., Private Benefits of Control in Founding-Family Owned Firms: An Analysis of the Dynamics of Disproportionate Ownership and Control in Family Firm IPOs (July 1, 2015), dostupno na: https://ssrn.com/ abstract=423506 (posjećeno 10. 1. 2019.)

13 Posebno se to odnosi na takve mehanizme kojima se uvode ograničenja u stjecanju dionica ili ograničenja u izvršavanju glasačkih prava.

14 Report of the High Level Group of Company Law Experts on Issues Related to Takeover Bids, Brussels, 10 January 2002, dostupno na: http://ec.europa.eu/internal_market/company/docs/ takeoverbids/2002-01-hlg-report_en.pdf (posjećeno 10. 1. 2019.). 
odlučivanja o primjeni protupreuzimateljske mjere, nije propisana obvezna primjena načela proporcionalnosti. ${ }^{15}$ Zbog toga se i dalje u društvima vrlo često koriste dionice koje daju nejednako pravo glasa, piramidalne strukture i drugi mehanizmi jačanja kontrole, ${ }^{16}$ koji svi predstavljaju odstupanje od načela proporcionalnosti.

Korporativni hrvatski milje, neovisno o tomu govorimo li o uvrštenim ili neuvrštenim dioničkim društvima (koja su pritom dio poslovnih grupacija), slijedi primjer kontinentalnog modela koncentriranog dioničarstva, a kao dominantni dioničari pojavljuju se pojedinci, obitelji, ali i država. ${ }^{17}$ Kada se radi o pojedincima ili obiteljima koji zauzimaju položaj dominantnih dioničara, jačanje glasačke snage uporabom mehanizama kojima se odstupa od načela proporcionalnosti, osim što smanjuje količinu kapitala kojeg je potrebno angažirati pri širenju poslovne grupacije, istodobno otvara prostor za povećanje pritiska na profesionaliziranu upravu, ${ }^{18}$ kako ista ne bi bila u iskušenju zanemariti interes društva na uštrb svog vlastitog interesa, u situacijama prijetnje promjene kontrole, ali i inače. No, ako je u tim društvima položaj većinskog dioničara i člana uprave sjedinjen u istoj osobi, tada motiv uvođenja mehanizama odstupanja od načela proporcionalnosti nije jačanje kontrole naspram

15 Ferrarini, G., One Share - One Vote: A European Rule? (January 2006). ECGI - Law Working Paper No. 58/2006., dostupno na: https://ssrn.com/abstract=875620, gdje se posebno osvrće na (ne)primjenu načela proporcionalnosti kod primjene pravila proboja, sukladno odredbama Direktive o ponudama za preuzimanje. Međutim, nužno je naglasiti da su načelno odstupanja od načela "jedna dionica-jedan glas" obuhvaćena pravilom o obvezi objavljivanja ponude za preuzimanje (engl. mandatory bid rule). Tako primjerice ako dioničar drži dionice s višestrukim pravom glasa, svi će se glasovi uzeti u obzir kod utvrđivanja nastanka obveze objavljivanja ponude za preuzimanje. Valja istaknuti da Direktiva o ponudama za preuzimanje ne propisuje metode za izračunavanje kontrolnog praga, niti propisuje što se sve uračunava u kontrolni prag, već ta pitanja prepušta državama članicama. O tome više vidjeti kod Čulinović-Herc, E., Zubović, A., Is there a need for a revision of the control threshold in Croatian takeover law?, SGEM 2016 Conference Proceedings on Political Sciences, Law, Finance, Economics \& Tourism, Volume II, Book 2, Bulgaria, 2016., str. 669 - 676.

16 Vidi Almeida, H., Wolfenzon, D., A Theory of Pyramidal Ownership and Family Business Groups, Journal of Finance, vol. 61, 2006., str. 2637-2681. Morck, R., The riddle of the great pyramids, cit., str. $602-628$.

Zattoni, A., The structure of corporate groups: The Italian case, Corporate Governance, vol. 7, 1/1999., str. 38-48. U studiji pod nazivom Report on the Proportionality Principle in the EU, koju su proveli ECGI, Shearman \& Sterling i Institutional Shareholder Services a koja je analizirala mehanizme za pojačanje kontrole u uvrštenim društvima iznosi se podatak da su najzastupljenji "pojačivači” kontrole piramidalne strukture, External Study Commissioned by the European Commission 18 MAY 2007, http://www.ecgi.org/osov/documents/final_report_ en.pdf, str. 22 (posjećeno 16. 1. 2019.).

17 Državni portfelj je znatno zastupljen. Bajo, A., Zuber, L., Primorac, M., Uspješnost financijskog poslovanja poduzeća (trgovačkih društava) u vlasništvu države, Fiscus, 5/ 2017, str. 2. Autori iznose podatak da je prema podatcima RGFI, Hrvatska 2016. u većinskom državnom vlasništvu imala 1.149 poduzeća. Od ukupnog broja poduzeća u 2017. navedenom u Prijedlogu plana za upravljanje državnom imovinom za 2017., više od 600 poduzeća je pod kontrolom opće države, ali u pretežnom vlasništvu jedinica lokalne i područne samouprave. Dostupno na: http://www. ijf.hr/upload/files/file/FISCUS/5.pdf (posjećeno 16. 1. 2019.).

18 Radi se o članovima uprave koji nisu ujedno većinski dioničari, već su angažirani zbog svojih stručnih kompetencija da bi vodili društvo. 
uprave društva, već služi kao mehanizam održavanja kontrole, odnosno ima funkciju preventivne protupreuzimateljske mjere, kako bi poslovna grupacija uvijek ostala u rukama dominantnog/dominantnih dioničara. Ono što je potvrđeno i u istraživanjima, jest da takav model otvara mogućnost prekomjernoga korištenja privatnih osobnih koristi većinskog dioničara na uštrb imovine društva, zbog faktične nemogućnosti da se manjina tomu suprotstavi. Pritom ta manjina, pogotovo ako su u pitanju društva koja su uvrštena, (opravdano) ima za cilj maksimizaciju dobiti. Prekomjerna kontrola svih funkcija u društvu koje kontrolira većinski dioničar povećava rizik moralnog hazarda i računovodstvenih manipulacija, no ovaj rad nema za cilj istražiti, tzv. abuzivne piramide koje se vrlo često pojavljuju ruku pod ruku s računovodstvenim manipulacijama. ${ }^{19}$

Zadatak je ovog rada kao prvo, smjestiti piramidalne strukture u širi kontekst mehanizama za povećanje kontrole, odnosno u taksonomiju mehanizama za povećanje kontrole. Nakon toga, s obzirom na to da se radi o mehanizmu koji je klasificiran kao mehanizam za povećanje kontrole koji je nastao na tržištu kapitala, u predmet istraživanja ovog rada će se uključiti i drugi takav mehanizam, a to su društva s uzajamnim udjelima. Prije detaljnije analize oba „mehanizma“ objasnit će se učinci koji se postižu kada se koriste mehanizmi jačanja kontrole u odnosu na uvrštena društva i to u scenariju dobrovoljnog i neprijateljskog preuzimanja, kao i u scenariju kada preuzimanja nema, vodeći pritom računa radi li se o društvu s disperziranom ili koncentriranom strukturom. Također će se iznijeti empirijski pokazatelji u kojoj mjeri se u pojedinim europskim državama koriste piramidalne strukture, odnosno društva s uzajamnim udjelima. Pri detaljnijoj analizi tih dvaju mehanizama odgovarajuća pozornost usmjerit će se na pitanje na koji način se izračunava glasačka snaga u

19 Od niza primjera velikih računovodstvenih manipulacija i financijskih prijevara iz prošlog stoljeća koji su protresli svijet, izdvajamo tri kojima je svojstveno da se društvo nalazilo pod kontrolom jedne osobe (pojedinca) što ilustrira problem moralnog hazarda i ulazak u kazneni prostor. Najpoznatiji je svakako Madoff skandal no on je specifičan zbog toga jer graniči s Ponzijevom shemom i podrazumijeva primjenu sofisticiranih manipulatornih investicijskih tehnika. Više o tome vidi: Čulinović-Herc, E., Grković, N., Odjeci financijskog skandala Madoff u parničnoj praksi zemalja članica Europske unije na primjeru fonda Luxalpha SICAV, Zbornik Pravnog fakulteta u Zagrebu, vol. 63, br. 3-4, 2013., str. 593-615., https://hrcak.srce. $\mathrm{hr} / 109721$ (posjećeno 16. 1. 2019.). Za potrebe ovog rada interesantan je slučaj Maxwell Communications. Robert Maxwell, medijski mogul, bio je s članovima svoje obitelji $100 \%$ dioničar svog poslovnog carstva Maxwell Communication u čijem su se portfelju nalazili vrlo poznati časopisi. Cijeli konglomerat bio je organiziran kroz tri holding kompanije koje su svaka za sebe imale na desetke ovisnih društava, također pod kontrolom obitelji. Kompanija je bila predmet istrage s obje strane Atlantika zbog prijevare, a istraga je pokrenuta kada je 2001. godine Maxwell, iznenada preminuo utopivši se u Atlantskom oceanu. Ispostavilo se da je istu imovinu davao više puta kao zalog za razne kredite raznim bankama, otuđio nezakonito 767 milijardi USD-a iz mirovinskog fonda svojih zaposlenika, što nije bilo računovodstveno evidentirano. Vjerovnici Maxwella nisu bili u potpunosti upoznati s korporativnom strukturom njegova poslovnog carstva. Sve ključne transakcije obavljale su se putem obiteljskog trusta osnovanog u Lihtenštajnu, čiji su porezni propisi i propisi o objavi računovodstvenih gotovo da i nisu postojali. Vidi više McCarroll, T. Scandal Maxwell's Plummet, Time Magazine, June 24, 2001, dostupno na: http://content.time.com/time/magazine/article/0,9171,156074,00.html (posjećeno 16. 1. 2019.). 
situacijama kada postoji odstupanje od načela proporcionalnosti.

\section{TAKSONOMIJA MEHANIZAMA ODSTUPANJA OD NAČELA PROPORCIONALNOSTI}

Piramidalne strukture spadaju u odstupanja od načela proporcionalnosti jer pribavljaju imatelju kontrole ,više kontrole“ nego što bi je imao svojim sudjelovanjem u osnivačkom kapitalu, odnosno omogućavaju dioničaru da poveća svoju kontrolu, a da istodobno (proporcionalno) poveća svoje sudjelovanje u temeljnom kapitalu društva. Prema jednoj podjeli, piramidalne strukture identificirane su kao jedan od ukupno trinaest pojavnih oblika mehanizama odstupanja od načela proporcionalnosti. Tako u studiji pod nazivom Report on the Proportionality Principle in the European Union iz 2007. godine ${ }^{20}$ piramidalne strukture su opisane kao odstupanje od načela ,jedna dionica - jedan glas“, odnosno mehanizam koji služi kao „pojačivač““ kontrole (engl. control-enhancing mechanisms, CEMs). ${ }^{21} \mathrm{U}$ studiji su opisani sljedeći mehanizmi:

1. Dionice s višestrukim pravom glasa (engl. multiple voting rights shares).

2. Dionice bez prava glasa koje ne spadaju u povlaštene dionice (engl. nonvoting shares-without preference).

3. Povlaštene dionice bez prava glasa (engl. non-voting preference shares), koje se od prethodnih razlikuju po tomu što se imatelje tih dionica zbog nepostojanja prava glasa „nagrađuje“ pojačavanjem financijskih prava - višom ili garantiranom dividendom.

4. Piramidalne strukture (engl. pyramid structures) koje se temelje na ideji da se učinak razdvajanja „vlasništva od kontrole“ (engl. separation of ownership and control) može postići primjenom lančanog pristupa, pa što je lanac držanja udjela/ dionica duži, odnosno piramida ,viša“, to dolazi do većeg odstupanja od načela proporcionalnosti, koje ponekad može graničiti i sa zlouporabom. Visoka skupina stručnjaka za pravo društava opisala je abuzivne piramide kao holding društva čija se jedina ili glavna imovina sastoji u držanju kontrolnih udjela u drugim uvrštenim društvima. ${ }^{22}$

20 Institutional Shareholder Services, ECGI, Shearman \& Sterling LLP, Proportionality between ownership and control in EU listed companies: External study commissioned by the European Commission, Report on the Proportionality Principle in the European Union, 18 May 2007. Dostupno na http://www.ecgi.org/osov/documents/final_report_en.pdf (posjećeno 16. 1. 2019.).

21 Institutional Shareholder Services, ECGI, Shearman \& Sterling LLP, Proportionality between ownership and control in EU listed companies: External study commissioned by the European Commission, Report on the Proportionality Principle in the European Union, 18 May 2007. Dostupno na: http://www.ecgi.org/osov/documents/final_report_en.pdf (posjećeno 16. 1. 2019.).

22 Iako su abuzivne piramide rijedak primjer, jedna je takva bila povod izradi UCITS V Direktive, odnosno opširnim konzultacijama koje je provela ESMA, krovni regulator europskog tržišta kapitala u povodum izrade mjera implementacije AIFM Direktive. Vidi: Consultation paper ESMA's draft technical advice to the European Commission on possible implementing measures of the Alternative Investment Fund Managers Directive July 2011 | ESMA/2011/209. Riječ je o prijevarnoj shemi Madoffovih master-feeder fondova koja je imala globalne razmjene. 
5. Dionice s pravom prvenstva koje daju njihovom imatelju posebno pravo veta neovisno o količini dionica koje imatelj drži (engl. priority shares).

6. Depozitarni certifikati, odnosno potvrde o dionicama u depozitu (engl. depository (share) certificates), radi se o financijskom instrumentu koji predstavlja dionice društva kojeg za dioničara drži depozitna institucija koja upravlja glasačkim pravima, s obzirom na to da u tom slučaju dioničar ne izvršava pravo glasa.

7. Dionice kod kojih se pravo glasa može izvršavati samo do određenog praga, iako dioničar može imati i više od toliko dionica (engl. voting right ceilings), pri čemu taj prag može biti izražen u postotku svih dionica koje imaju pravo glasa (npr. ne više od $3 \%$ svih dionica s pravom glasa) ili u postotnom iznosu svih glasova dioničara koji su glasovali na održanoj glavnoj skupštini.

8. Ograničenja u prijenosu dionica (engl. share transfer restrictions ili ownership ceilings), gdje nije moguće u određenom društvu steći više od određenog postotka dionica s pravom glasa, odnosno preko određenog praga.

9. Odredbe o odlukama koje se moraju donijeti kvalificiranom većinom (engl. supermajority provisions), odnosno većinom većom od $50 \%$ prava glasa + jedan glas.

10. Države koje poznaju komanditna društva na dionice (engl. partnerships limited by shares), s obzirom na to da se radi o društvu s dvije vrste članova, pri čemu oni koji ulažu kapital (komanditori) imaju samo pravo nadzora, ali ne i pravo glasa, koje pripada komplementarima koji odgovaraju neograničeno za obveze društva.

11. Zlatne dionice (engl. Golden shares) opisane su kao takav mehanizam jačanja kontrole u kojem takve dionice imaju posebna prioritetna prava u korist države ili institucija lokalne samouprave putem kojih država ili lokalna samouprava kontrolira privatizirane kompanije jer su u tim dionicama sadržana prava koja daleko premašuju uobičajen sadržaj prava iz redovite dionice.

12. Društva s uzajamnim udjelima (engl. Cross-shareholdings).

13. Sporazumi dioničara (engl. Shareholders agreements).

Prema drugoj podjeli (ECGF) mehanizmi odstupanja od načela proporcionalnosti svrstavaju se u četiri skupine. Prvom skupinom obuhvaćeni su mehanizmi sadržani u temeljnim aktima kojima se izravno utječe na pravo glasa dioničara, poput dionica $\mathrm{s}$ višestrukim pravom glasa, dionica bez prava glasa i dionica uz ograničenje prava glasa. Drugom skupinom obuhvaćeni su mehanizmi sadržani u temeljnim aktima društva kojima se izravno ne utječe na pravo glasa koje proizlazi iz dionice, već daju posebna prava koja smanjuju ili zabranjuju proporcionalno ostvarivanje prava glasa, primjerice dionice koje daju pravo na imenovanje članova upravljačkih tijela društva. Treća skupina mehanizama obuhvaća mehanizme koji su sadržani u temeljnim aktima društva, a kojima se smanjuje ili zabranjuje ostvarivanje kontrole korištenjem pravom glasa. Ovom su skupinom obuhvaćena ograničenja prijenosa dionica kao i postojanje stupnjevanog odbora u društvu. Četvrta skupina mehanizama kojom se utječe na proporcionalnost prava glasa i udjela u temeljnom kapitalu društva obuhvaća mjere

Više vidi: Čulinović-Herc, E., Grković, N., Impact of the Madoff Scandal on the Forthcoming UCITS V Directive, u: V. Kandžija, A. Kumar, (ur.), Economic integrations, competition and cooperation: Accession of the Western Balkan Countries to the EU, Rijeka, Ekonomski fakultet u Rijeci, 2013., str. 168-182. 
koje nisu sadržane u temeljnim aktima društva, već su se razvile na tržištu kapitala, primjerice piramidalne strukture i uzajamni udjeli kao i mjere koje dovode do neproporcionalnog odnosa upravljačkih i imovinskih prava kroz tržišne instrumente, poput pozajmljivanja dionica (engl. securities lending), equity swaps ${ }^{23}$ i opcija (engl. options). ${ }^{24}$ Riječ je o mehanizmima koji dovode do pojava koje se nazivaju empty voting i hidden (morphable) ownership. ${ }^{25}$ Prema podatku koji se iznosi u Studiji International Shareholder Services, ECGI i Sherman \& Sterling, odstupanja koja su ulagatelji ocijenili kao najnegativnija su redom: izdavanje prioritetnih dionica (engl. priority shares), zatim kao negativna odstupanja slijede zlatne dionice, piramidalne strukture, dionice s višestrukim pravom glasa te dionice uz ograničenje prava glasa. ${ }^{26}$

\section{KOJI SE UČINCI POSTIŽU PRIMJENOM NAVEDENIH ODSTUPANJA OD NAČELA PROPORCIONALNOSTI?}

Učinci navedenih mehanizama ogledaju se u mnogim scenarijima koji su mogući u poslovnom ciklusu društva. U prvom redu ti mehanizmi snažno utječu na postupke prijateljskog ili neprijateljskog preuzimanja (uvrštenog) društva, odnosno na situacije kada dolazi do promjene kontrole. Pritom treba razlikovati radi li se o ciljnom društvu s disperziranom ili koncentriranom korporativnom strukturom. No, učinci ovih mehanizama vidljivi su i izvan preuzimateljskog scenarija. Oni se posebno prelamaju na odnose između većinskih dioničara i uprave, a također utječu na promjenu odnosa između većinskih i manjinskih dioničara. Kada se radi o neprijateljskom preuzimanju, pojavljuju se kao vid odvraćajuće protupreuzimateljske mjere, odnosno instrumenti za, tzv. ,zaključavanje“ kontrole.

23 Čulinović-Herc, E., Zubović, A., Cash Settled Derivatives and Their Role in Companies' Takeovers, u Bodiroga-Vukobrat, N., Rodin, S., Sander, G. G. (eds.), Europeanization and Globalization, New Europe - Old Values?, Reform and Perseverance, vol. 1, Springer, 2016., str. 235-267.

24 Paper of the European Corporate Governance Forum Working Group on Proportionality, June 2007, dostupno na: http://ec.europa.eu/internal_market/company/docs/ecgforum/ workinggroup_proportionality_en.pdf, (posjećeno 16.1.2019.), str. 1 i 10, gdje se ističe da ne postoji striktna podjela mehanizama u navedene četiri skupine, već određeni mehanizam kojim se odstupa od načela proporcionalnosti može biti obuhvaćen u više skupina.

25 Više o tome vidi: Čulinović-Herc, E., Zubović, A., Tackling Empty Voting in EU - Shareholders' Rights Directive and Revised Transparency Directive, Croatian Yearbook of European Law and Policy, vol. 11, 2015., str. 133-160. Hu, Henry, T. C., Black, B., Empty Voting and Hidden (Morphable) Ownership: Taxonomy, Implications, and Reforms, The Business Lawyer, vol. 61, 3/2006, str. 1011-1070. Hu, Henry, T. C., Black, B., The New Vote Buying: Empty Voting and Hidden (Morphable) Ownership, Southern California Law Review, vol. 79, 2006., str. 811; Ringe W.-G., Hedge Funds and Risk-Decoupling: The Empty Voting Problem in the European Union, Oxford Legal Studies Research Paper No 52, 2012., dostupno na: http://ssrn.com/ abstract=2135489 (posjećeno 16. 1. 2019.).

26 Institutional Shareholder Services, ECGI, Shearman \& Sterling LLP, Proportionality between ownership and control in EU listed companies: External study commissioned by the European Commission, Report on the Proportionality Principle in the European Union, 18 May 2007. Dostupno na: http://www.ecgi.org/osov/documents/final_report_en.pdf, str. 9. (posjećeno 16. 1. 2019.). 


\subsection{Učinci pri promjeni kontrole nad uvrštenim društvom (preuzimanje)}

Znanstvena istraživanja o učincima odstupanja od načela ,jedna dionica jedan glas" u postupcima preuzimanja iznose zaključak da ti učinci ovise o strukturi dioničara u društvu. ${ }^{27}$ Ako se radi o ciljnom društvu s disperziranom korporativnom strukturom, a u postupku preuzimanja se natječu dva ponuditelja, načelo ,jedna dionica - jedan glas" osigurava da najbolji ponuditelj odnosi pobjedu. ${ }^{28}$ Ako se radi o jednom ponuditelju, okolnost da postoje dionice koje daju različito pravo glasa „ruši“ cijenu dionice po kojoj su postojeći dioničari voljni prodati. Time se (jedinom) ponuditelju smanjuju troškovi preuzimanja, što povećava njegovu korist i što ga dodatno motivira na preuzimanje. Dakle, načelo proporcionalnosti je optimalno rješenje u situaciji kada postoje dva ili više ponuditelja, a ciljno društvo ima disperziranu strukturu. Iz kuta interesa dioničara koji su adresati ponude, ako postoje dva ponuditelja, dioničarima će više odgovarati odstupanje od načela proporcionalnosti jer se vode mišlju da će za svoje dionice s pravom glasa dobiti veću premiju od takmaca koji pobjeđuje jer će on svojom pobjedom zadobiti jaču kontrolu. Ako je riječ o scenariju s jednim ponuditeljem, tada se pri donošenju odluke o prihvaćanju ponude za preuzimanje, dioničari ionako ne rukovode ponuditeljevim motivima (uštede/koristi), već u prvom planu imaju jedino svoju korist. ${ }^{29}$

S druge strane, ako je riječ o ciljnom društvu koje ima koncentriranu dioničarsku strukturu, načelo proporcionalnosti potiče takvu promjenu kontrole koja donosi povećanje vrijednosti i učinkovito zatire takvu promjenu kontrole koja bi dovela do smanjenja vrijednosti (engl. value decreasing) ${ }^{30}$ no općenito ne osigurava učinkovitu alokaciju kontrole. Zbog toga jer pri promjeni kontrole ponuditelj ne promišlja na koji način će se promjena kontrole odraziti na „bogatstvo“ manjinskih dioničara. Ako postoje konkurentske ponude, odstupanja od načela proporcionalnosti pogoduju ostvarenju bolje cijene, odnosno veće premije, pa su stoga optimalna za dioničare. ${ }^{31}$

27 Geens, K., Clottens, C., One Share - One Vote: Fairness, Efficiency and (the Case for) EU Harmonisation Revisited, u: Hopt, K., J., Geens, K., (eds.) The European Company Law Action Plan Revisited, Reassessment of the 2003 priorities of the European Commission, Leuven University Press, 2010., dostupno na: http://ssrn.com/abstract=1547842 (posjećeno 14.1.2019.). Khachaturyan, A., The One-Share-One-Vote Controversy in the EU, ECMI Paper No. 1/2006, August 2006, http://ssrn.com/abstract=908215 (posjećeno 14.1.2019.).

28 Khachaturyan, A., The One-Share-One-Vote Controversy in the EU, ECMI Paper No. 1/2006, August 2006, str. 11-12., dostupno na: http://ssrn.com/abstract=908215 (posjećeno 14.1.2019.).

29 External Study Commissioned by the European Commission 18.05.2007, dostupno na: http:// www.ecgi.org/osov/documents/final_report_en.pdf, str. 15 (posjećeno 16. 1. 2019.).

30 loc. cit.

31 loc. cit. Vidi još: Bennedsen, M., Nielsen, K. M., The Principle of Proportional Ownership, Investor Protection and Firm Value in Western Europe, 2008., str. 35, iznose podatak da zapadnoeuropska uvrštena društva koja ne odstupaju od načela proporcionalnosti imaju veću "firm value". dostupno na: https://pdfs.semanticscholar.org/1135/ a33bb5598adb88127dce380388229d8f437e.pdf (posjećeno: 21.01.2019.) 


\subsection{Utjecaj na jačanje položaja većinskog dioničara u odnosu na upravu (i manjinske dioničare)}

U društvima disperzirane strukture odstupanja od načela proporcionalnosti najviše dolaze do izražaja pri preuzimanju. Izvan tog scenarija disperzirani dioničari općenito su nemotivirani nadzirati upravu i izvršavati svoje pravo glasa. Za razliku od njih, veliki dioničari u društvima koncentrirane dioničarske strukture su itekako voljni i u mogućnosti nadzirati upravu. ${ }^{32} \mathrm{~S}$ obzirom na to da držanje velikog udjela nosi sa sobom i troškove, veliki dioničari u pravilu žele ograničiti svoj većinski blok. $\mathrm{S}$ jačanjem glasačke snage (odnosno odstupanjem od načela proporcionalnosti) veliki dioničar povećava sebi mogućnost discipliniranja članova uprave. U tom je smislu uvođenje mehanizma za povećanje kontrole dobrodošlo, jer ublažava sukob interesa između većinskog dioničara i uprave te se pozitivno odražava na opću dobrobit svih dioničara. Većinski dioničar može koristiti polugu jačanja glasačke snage ne samo da ojača svoj položaj u odnosu na upravu, već i da poduzme akcije koje su isključivo u njegovom interesu. ${ }^{33}$ Dakle, iako dolazi do ublažavanja sukoba interesa između većinskog dioničara i uprave, pojačava se sukob interesa između manjinskih i većinskog dioničara. ${ }^{34}$ Naprotiv, ako se društvo drži načela proporcionalnosti, to štiti manjinske dioničare od toga da se većinski dioničar prekomjerno koristi imovinom društva za svoje osobne koristi, ali ostavlja i upravi veću dozu diskrecije u slijeđenju svojih vlastitih ciljeva. ${ }^{35}$

\subsection{Utjecaj na prijetnju promjene kontrole, odnosno težnja zadržanja kontrole kada je dovedena u pitanje}

Situacije u kojima ciljnom društvu „prijeti“ preuzimanje mogu imati disciplinatorni učinak na ponašanje svih unutrašnjih dionika u društvu koji su

32 Institutional Shareholder Services, ECGI, Shearman \& Sterling LLP, Proportionality between ownership and control in EU listed companies: External study commissioned by the European Commission, Report on the Proportionality Principle in the European Union, 18 May 2007, str. 15. Dostupno na: http://www.ecgi.org/osov/documents/final_report_en.pdf str. 15 (posjećeno 16. 1. 2019.).

33 Loc. cit.

34 Edwards, J., Weichenrieder, Alfons J., How Weak is the Weakest-Link Principle? On the Measurement of Firm Owners' Control Rights (August 2004). CESifo Working Paper Series No. 1255., str. 3, dostupno na: https://ssrn.com/abstract=591902 (14.1.2019.), ističu da je kod odstupanja od načela proporcionalnosti upravo najveći problem sukoba interesa između većinskog i manjinskih dioničara društva. Ringe, W.-G., Deviations from Ownership-Control Proportionality_Economic Protectionism Revisited, u Bernitz, U., Ringe, W-G., (eds), Company Law and Economic Protectionism, Oxford University Press, 2010., str. 221, ističe da je takav sukob osobito izražen u društvima u kojima prevladava koncentrirana struktura dioničara.

35 Institutional Shareholder Services, ECGI, Shearman \& Sterling LLP, Proportionality between ownership and control in EU listed companies: External study commissioned by the European Commission, Report on the Proportionality Principle in the European Union, 18 May 2007, str. 15. Dostupno na: http://www.ecgi.org/osov/documents/final_report_en.pdf, str. 15. (posjećeno 16. 1. 2019.). 
ujedno i upućene osobe, jer im je zabranjeno poduzimati radnje kojima bi doveli do smanjenja vrijednosti ciljnog društva, u želji da „spase ključnu imovinu“ i osujete ponuditeljeve neprijateljske namjere. Ako se radi o društvu u kojem se poštuje načelo proporcionalnosti to dovodi do usklađivanja interesa između dioničara koji su ujedno korporativni insideri i oni koji to nisu jer glasačka i imovinska prava iz dionice dolaze u proporciji. ${ }^{36}$

Ako glasačka i imovinska prava nisu razmjerna, pa insider ima više glasačkih prava od prava na dividendu, tada ga to bolje štiti od preuzimanja, ali ga udaljava od interesa drugih dioničara outsidera, s kojima nije više usklađen. ${ }^{37}$ Razdioba glasačkih prava može biti i drukčije postavljena, tako da uprava ima veliki blok dionica, ali bez prava glasa. U poslovnoj praksi to ovisi o stilu vođenja. Društva ili vode insideri koji imaju veliki blok glasačkih prava pa su na taj način zaštićeni od neprijateljskih preuzimanja ili se radi o tomu da ciljno društvo disperzirane strukture vodi profesionalna uprava koja je itekako osjetljiva na neprijateljsko preuzimanje. ${ }^{38}$ Čini se da je pravo pitanje upravljaju li učinkovitije društvima profesionalni menadžeri (koji mogu biti otpušteni) ili veliki ukorijenjeni „vlasnici“. Činjenica je da su se najveći skandali korporativnog upravljanja dogodili i u disperziranom Enronu i Parmalatu - društvu s dominantnim dioničarima ${ }^{39}$ No, ako postoji prijetnja preuzimanja uobičajen odgovor na to je poduzimanje protupreuzimateljskih mjera, ${ }^{40}$ što definitivno može utjecati na promjenu strateških ciljeva specifičnih za društvo, planova dugoročnih investicija, pa je uobičajena percepcija da preuzimanje više smanjuje, odnosno redistribuira vrijednost društva, nego što ga povećava ${ }^{41}$

Korištenje mehanizama odstupanja od načela proporcionalnosti uočeno je kod obiteljskih društava u situacijama kada u korporativnu strukturu ulaze novi članovi. Tada najčešće postojeći članovi društva (obitelj) korištenjem nekoga od mehanizma odstupanja od načela proporcionalnosti, primjerice dionice s višestrukim pravom glasa ili dionice koje daju neka posebna prava, nastoje zadržati kontrolu nad društvom. ${ }^{42}$

36 Loc. cit.

37 Loc. cit.

38 Loc. cit.

39 Prikaz navedenih skandala s njihovim posljedicama vidi: Jurić, D., Uloga revizora u dioničkom društvu, Zbornik Pravnog fakulteta Sveučilišta u Rijeci, vol. 25, 1/2004., str. 323-352.

40 Jurić, D., Zubović, A., Protupreuzimateljske mjere i položaj uprave ciljnog društva, Zbornik Pravnog fakulteta Sveučilišta u Rijeci, vol. 30, 1/2009., str. 291-331.

41 Institutional Shareholder Services, ECGI, Shearman \& Sterling LLP, Proportionality between ownership and control in EU listed companies: External study commissioned by the European Commission, Report on the Proportionality Principle in the European Union, 18 May 2007, str. 16. Dostupno na: http://www.ecgi.org/osov/documents/final_report_en.pdf, str. 15 (posjećeno 16. 1. 2019.).

42 Ehrhardt, O., Nowak, E., Private Benefits of Control in Founding-Family Owned Firms: An Analysis of the Dynamics of Disproportionate Ownership and Control in Family Firm IPOs (July 1, 2015), str. 13, dostupno na: https://ssrn.com/abstract=423506, na uzorku od 105 obiteljskih društava u Njemačkoj koja su uvrstila svoje dionice na uređeno tržište kapitala (od siječnja 1970. godine do prosinca 1991. godine), 20 godina nakon uvrštenja, od njih 90 koja su još poslovala, obitelji su zadržale kontrolu nad 37 društava. 


\subsection{Utjecaj na ograničenje prenosivosti dionice}

Ovi mehanizmi ponajprije služe za, tzv. zaključavanje kontrole. ${ }^{43}$ Postoji ograničenje stjecanja određenog broja dionica do nekoga praga i ograničenje glasovanja do nekog praga, neovisno o broju dionica koje se drže. Iako ti najviši dopustivi pragovi držanja dionica ili korištenja prava glasa strogo gledano nisu odstupanje od načela proporcionalnosti, oni sprječavaju pojedine dioničare da akumuliraju znatan udio i glasačku moć, čime se ograničava njihova mogućnost utjecaja na donošenje korporativnih odluka. Nasuprot prethodnim mehanizmima bildanja glasačke kontrole ovi mehanizmi služe, tzv. razrjeđivanju kontrole, ${ }^{44}$ odnosno njima se ometa nastajanje i djelovanje velikih dioničara te time praktički čine preuzimanja nemogućim. Ovi se mehanizmi smatraju opravdanima u situacijama kada bi neki dioničar htio steći kontrolu i tako „opljačkati“ manjinske dioničare. ${ }^{45}$ No, s ,,razrjeđivanjem kontrole“ većinskog dioničara raste moć uprave, jer ona počinje izmicati učinkovitu nadzoru velikog dioničara. ${ }^{46}$ Time se istodobno potkopavaju dva modaliteta discipliniranja uprave: vanjsko praćenje i strah od promjene kontrole.

\section{EMPIRIJSKI POKAZATELJI U EUROPSKIM DRZ̆AVAMA O ODSTUPANJU OD NAČELA PROPORCIONALNOSTI}

Institutional Shareholder Services u suradnji s European Corporate Governance Institute i društvom Sherman \& Sterling, proveli su istraživanje o zastupljenosti mehanizama odstupanja od načela proporcionalnosti na uzorku od 464 društava u 16 europskih država. ${ }^{47}$ Rezultati istraživanja objavljeni su 2007. godine kao dio opsežne studije Europske komisije. ${ }^{48} \mathrm{U}$ studiji se iznosi podatak da niti jedan od ispitanih pravnih poredaka nije u cijelosti prihvatio načelo,,jedna dionica-jedan glas“" te podatak da je $44 \%$ od ispitanih europskih društava usvojilo barem jedan način odstupanja

43 Institutional Shareholder Services, ECGI, Shearman \& Sterling LLP, Proportionality between ownership and control in EU listed companies: External study commissioned by the European Commission, Report on the Proportionality Principle in the European Union, 18 May 2007, str.

16. Dostupno na: http://www.ecgi.org/osov/documents/final_report_en.pdf, str. 15 (posjećeno 16. 1. 2019.).

44 Loc. cit.

45 Burkart, M., Lee, S., The One Share - One Vote Debate: A Theoretical Perspective Finance Working Paper N ${ }^{\circ} .176 / 2007$, May 2007, dostupno na: http://ssrn.com/abstract_id=987486, str. 33. (posjećeno 16. 1. 2019.).

46 Vidi više: Goergen, M., Martynova, M., Renneboog, L., Corporate Governance Convergence: Evidence From Takeover Regulation Reforms in Europe, Oxford Review of Economic Policy, vol. 21, br. 2, str. 243-268.

47 Istraživanje je provedeno u Belgiji, Danskoj, Estoniji, Finskoj, Francuskoj, Njemačkoj, Grčkoj, Mađarskoj, Irskoj, Italiji, Luksemburgu, Nizozemskoj, Poljskoj, Španjolskoj, Švedskoj i Velikoj Britaniji. Rezultati istraživanja obuhvaćaju i podatke iz SAD-a, Japana i Australije.

48 Institutional Shareholder Services, ECGI, Shearman \& Sterling LLP, Proportionality between ownership and control in EU listed companies: External study commissioned by the European Commission, Report on the Proportionality Principle in the European Union, 18 May 2007., dostupno na: http://www.ecgi.org/osov/documents/final_report_en.pdf, str. 1-216. (posjećeno 16. 1. 2019.). 
od načela ,jedna dionica - jedan glas“. Najčešći način odstupanja su piramidalne strukture ( $27 \%$ ispitanih društava) ${ }^{49}$ zatim slijede dionice s višestrukim pravom glasa ( $24 \%$ ispitanih društava) te sporazumi dioničara (12 \% ispitanih društava). Međutim, nužno je istaknuti postojanje razlika unutar pojedinih država. Dok su piramidalne strukture najčešće u Belgiji (34 \%) i Švedskoj (48 \%) samo nekolicina društava u Velikoj Britaniji primjenjuje ovu mjeru (3\%), dok je društva sa sjedištem u Danskoj ne primjenjuju. Dionice s višestrukim pravom glasa uobičajene su u Švedskoj (59 \%), Francuskoj (58 \%) i Nizozemskoj (41 \%). Društva s uzajamnim udjelima egzistiraju u $31 \%$ država koje su sudjelovale u istraživanju. Najveća je zastupljenost u Švedskoj (25\%), zatim slijede Francuska (20\%), Nizozemska (11\%) te Njemačka (10\%). Na uzorku od 464 društava na $3 \%$ društava odstupanje od načela proporcionalnosti učinjeno je kroz uzajamne udjele. Sumarno se iznosi podatak da najveći broj društava koja primjenjuju odstupanja imaju sjedište u Francuskoj, Švedskoj, Mađarskoj, Italiji i Španjolskoj.

Do sličnih se rezultata došlo u znanstvenom istraživanju kojega su proveli Bennedsen i Nielsen, ${ }^{50}$ a koje je provedeno na uzorku većem od 4.000 društava u 14 zapadnoeuropskih zemalja. Ključna je razlika u podatku o broju društava koja koriste piramidalne strukture i dionice koje daju različita prava, kao načini odstupanja od načela proporcionalnosti u Velikoj Britaniji. Tako se iznosi da se piramide koriste u 22 \% društava, dok dionice s različitim pravima izdaje $25 \%$ društava, što je mnogo viši postotak od onog navedenog u Studiji ISS-a, kao i općeprihvaćenom stajalištu da su odstupanja od načela ,jedna dionica - jedan glas“ u Velikoj Britaniji rijetka.

Rezultati istraživanja provedenoga u Italiji pokazuju da je broj piramidalnih struktura 1993. godine iznosio 56,5\%, dok je 2005. godine iznosio 45,8 \%. ${ }^{51}$ Dakle, provedeno istraživanje iznosi zaključak da je došlo do pada zastupljenosti piramidalnih struktura.

Istraživanje kojega su u Francuskoj proveli Ginglinger i Hamon ${ }^{52}$ na uzorku od 1.550 društava iznosi podatak da broj piramidalnih struktura u Francuskoj iznosi 18,5 $\% .53$

Masulis, Pham, i Zein ${ }^{54}$ iznose podatak da je od 28.635 društava iz 45 država,

49 Za određivanje radi li se o piramidalnoj strukturi u studiji je primijenjen prag od $5 \%$ držanja dionica kod izravnog držanja dionica, odnosno prag od $20 \%$ za neizravno držanje dionica.

50 Bennedsen, M., Nielsen, K. M., The Principle of Proportional Ownership, Investor Protection and Firm Value in Western Europe (October 2006). ECGI - Finance Working Paper No. 134/2006, dostupno na: https://ssrn.com/abstract=941054 (posjećeno 16. 1. 2019.)

51 Bianchi, M., Bianco, M., Italian Corporate Governance in the Last 15 Years: From Pyramids to Coalitions? (November 2006). ECGI - Finance Working Paper No. 144/2006., dostupno na: https://ssrn.com/abstract=952147 (posjećeno 16. 1. 2019.).

52 Ginglinger, E., Hamon, J., Ownership, Control and Market Liquidity (June 1, 2012). Finance, 2012, vol. 33, 2, str. 61-99, dostupno na: https://ssrn.com/abstract=2097795, str. 13.

53 U istraživanju je primijenjeno načelo "najslabije karike", pri čemu je za određivanje radi li se o piramidalnoj strukturi korišten prag od $20 \%$ glasačkih prava u društvu.

54 Masulis, R. W., Pham, P. K., Zein, J., Family Business Groups around the World: Financing Advantages, Control Motivations and Organizational Choices (April 21, 2011). Review of Financial Studies, Forthcoming; ECGI - Finance Working Paper No. 240/2009., dostupno na: https://ssrn.com/abstract=1363878, str. 3 (posjećeno 16. 1. 2019.). 
koja su korištena kao uzorak njihova istraživanja, 19 \% uvrštenih društava pod kontrolom obitelji, ${ }^{55}$ pri čemu na pojedinim tržištima taj postotak doseže i do 40 \%. Ističu da se društva povezuju na dva načina. Jedna trećina društava povezana je kroz horizontalne strukture $u$ kojima kontrolni dioničar (društvo) izravno drži udio u svim društvima u koncernu (grupaciji), dok je dvije trećine društava povezano kroz piramidalne strukture. Dalje se iznosi podatak da se u obiteljskim društvima koriste različiti mehanizmi odstupanja od načela proporcionalnosti od čega najviše društva s uzajamnim udjelima (10\% grupe) i dionice koje daju različita prava (15\% grupe).

\section{POSEBNO O MEHANIZMIMA KOJI SU SE RAZVILI NA TRŽIŠTU KAPITALA}

\subsection{Piramidalne strukture}

O piramidalnim strukturama (engl. Pyramid structures) je riječ kada određeni pravni subjekt ostvaruje kontrolu nad društvom koje drži kontrolni udjel u drugome društvu, što se može ponavljati više puta. Ova se metoda temelji na tomu da se disproporcionalan odnos između upravljačkih prava i udjela u temeljnom kapitalu može postići povezivanjem nekoliko društava. ${ }^{56}$ Što je više društava uključeno u piramidalnu strukturu veće je odstupanje od proporcionalnosti odnosa upravljačkih prava i udjela u temeljnom kapitalu društva. Piramidalne strukture svojstvene su koncentriranom modelu dioničarstva u kojem većinski dioničar često ima velike osobne pogodnosti, smanjen je pritisak za isplatu dividende te su povećani izgledi reinvestiranja dobiti u istraživanje i razvoj jer se radi o dioničaru s dugoročnim horizontom ulaganja.

Ako je pojedinačni dioničar ili obitelj ta koja kontrolira društvo, odnosno povezana društva, učinak piramidalne strukture postiže se ako se držanje udjela / dionica u tim društvima strukturira „lančano“. Obitelj, primjerice, izravno kontrolira jedno društvo, a to društvo kontrolira neko drugo u istoj grupaciji, koje opet kontrolira treće društvo i tako dalje. I u hrvatskom korporativnom miljeu, veliki broj uvrštenih, ali i neuvrštenih dioničkih društava nalazi se pod kontrolom pojedinaca ili obitelji, uobičajeno organiziranih kao niz povezanih društava. U tom smislu hrvatski korporativni model nimalo ne odstupa od dominantnog modela koji je prisutan u kontinentalnoj Europi. U literaturi se postojanje piramidalnih struktura objašnjava na način da one služe odvajanju glasačkih prava od utjecaja na novčane tijekove društva, s obzirom na to da obitelj koristi piramidu tako da društvo koje ona izravno kontrolira osniva drugo društvo. ${ }^{57}$ Tako se navodi primjer obitelji koja ima izravni udio u društvu u visini od $50 \%$. Ako to izravno kontrolirano društvo ima udio u drugom društvu u iznosu od $50 \%$, tada obitelj koja kontrolira prvo društvo ostvaruje (neizravnu)

55 U istraživanju je primijenjen prag od $20 \%$ glasačkih prava za određivanje ima li dioničar položaj kontrolnog dioničara.

56 Denis, D. K., McConnell, J. J., International Corporate Governance, Purdue CIBER Working Papers, Paper 17, 2007., http://docs.lib.purdue.edu/ciberwp/17, str. 35, Almeida, H., Wolfenzon, D., op. cit., str. 2637-2681.

57 Almeida, H., Wolfenzon, D., op. cit., str. 2637-2681. 
kontrolu i nad drugim društvom već i činjenicom neizravnog unosa $25 \%$ temeljnog kapitala u to drugo društvo ,putem društva kojeg izravno kontrolira“. Zbog toga se još i navodi da je smisao piramida, odvajanje ,vlasništva“ od kontrole.$^{58}$ No, nasuprot tome postoje mnogi primjeri u kojima je učinak odvajanja toliko neznatan da se njime ne može opravdati uporaba piramide. ${ }^{59}$

Piramidalne strukture jedno su od najčešćih i najšire primjenjivih odstupanja od načela proporcionalnosti. Ovo odstupanje podložno je određenim ograničenjima, pa povezivanje može biti ograničeno ili zabranjeno. ${ }^{60} \mathrm{U}$ cilju ograničavanja piramidalnih struktura, u SAD-u su još tridesetih godina prošloga stoljeća doneseni propisi o dvostrukom oporezivanju unutarkorporativnih dividendi (engl. double taxation of inter-corporate dividends). Temeljni razlog za taj regulatorni zahvat ciljao je upravo na smanjenje, odnosno uklanjanje piramida. ${ }^{61}$ Piramidalne strukture opisivane su kao višerazinski korporativni lanci u kojima su investitori na vrhu piramide uspjeli iskoristiti relativno mala ulaganja u jedno društvo kako bi ostvarili moć i utjecaj nad velikom skupinom društava (kćeri i unuka) na dnu piramide. Iako porezni udar na piramide nije bio dovoljno jak da bi odmah proizveo promjene u organizacijskoj strukturi $^{62}$ to je bio samo jedan od pravaca zakonodavne kampanje protiv piramida, koja je okrunjena donošenjem Public Utility Holding Company Acta, nakon koje su uslijedile strukturne promjene. ${ }^{63}$ Donesenim propisima postigli su se namjeravani ciljevi, odnosno došlo je do znatnoga smanjenja broja piramidalnih struktura u SADu. ${ }^{64}$

Iz navedenog primjera SAD-a vidljivo je da se smisao piramidalnih struktura

58 Stijn, C., Djankov, S., Lang, L. H. P., The separation of ownership and control in East Asian Corporations, Journal of Financial Economics, vol. 58., str. 81-112.

59 Franks, J., Mayer, C., Ownership and control of German corporations, Review of Financial Studies, vol. 14., 2001., str. 943-977.

60 Institutional Shareholder Services, ECGI, Shearman \& Sterling LLP, Proportionality Between Ownership and Control in EU Listed Companies: Comparative Legal Study, Exhibit C, (Part I), Legal Study for Each Iurisdiction. str. 330 iznosi se primjer Italije koja zabranjuje uvrštenje društvima koja koriste tzv. multi-layer listing, odnosno uvrštenje takvih društava čija se glavna imovina ili prihodi sastoje iz dionica drugih uvrštenih društava, dostupno na: http://www.ecgi. org/osov/documents/study-exhibit_c_part1_en.pdf (posjećeno 16.1.2019.).

61 Morck, R., How to Eliminate Pyramidal Business Groups: The Double Taxation of Intercorporate Dividends and Other Incisive Uses of Tax Policy, 19 TAX POL'Y \& ECON. 135, 136 (2005). Ferrarini, G., One Share - One Vote: A European Rule? (January 2006). ECGI - Law Working Paper no. 58/2006., str. 16, dostupno na: https://ssrn.com/abstract=875620 (posjećeno 16. 1. 2019.).

62 Bank, A., S., Cheffins, R., B., The Corporate Pyramid Fable, 84 Business History Review, 2010., str. 435, 443-445.

63 Public Utility Holding Company Act of 1935, Pub. L. No. 74-333,49 Stat. 803. Vidi povijesni pregled razvoja Bank, A., Steven, When We Taxed the Pyramids, Florida State University Law Review, vol 41, 1/2013., dostupno na http://ir.law.fsu.edu/lr/vol41/iss1/3, str. 40, 41. (posjećeno 16. 1. 2019.).

64 Promjene su se dogodile početkom četrdesetih godina prošlog stoljeća nakon što su društva reorganizirana prema Public Utility Holding Company Act iz 1935. godine. Vidi detaljnije, Bank, A., S., When We Taxed the Pyramids, Florida State University Law Review, vol 41, 1/2013., str. 41., dostupno na: http://ir.law.fsu.edu/lr/vol41/iss1/3 (posjećeno 16. 1. 2019.). 
ne može objasniti samo putem separacijskog učinka „vlasništva“ od kontrole, već nedvojbeno postoje i porezni motivi. To se može povezati s činjenicom da se isti separacijski efekt može postići s uvođenjem dionica s različitim pravom glasa, no opet ostaje pitanje zbog čega se piramidalne strukture koriste više od dionica koje daju različito pravo glasa. Iako prema pravu društava postoje ograničenja u korištenju dionica koje daju različito pravo glasa, ipak, ta ograničenja nisu tako stroga da bi bila razlog toliko veće zastupljenosti piramidalnih struktura, pa se opravdanim dade zaključiti da njihovo postojanje ispunjava još neke svrhe. ${ }^{65}$ Almeida i Wolfenzon ${ }^{66}$ smatraju da su piramide atraktivne ako su vanjski izvori financiranja osnivanja društva skuplji od unutrašnjih, a od obitelji se očekuje pribavljanje znatnoga dijela financiranja. Također smatraju da poslovne grupe koje nastaju kao poslovne grupacije pod kontrolom jedne obitelji vrlo često usvajaju model piramidalne strukture. Pri pokušaju da odgovore na pitanje zbog čega se obiteljska imovina usitnjava u pravno odvojene poslovne subjekte te koji su razlozi odabira hoće li obitelj usvojiti piramidalnu (ili horizontalnu, odnosno kompleksnu) strukturu autori nalaze razloge u nedostatnoj zaštiti ulagatelja i financijskim prednostima za obitelj koja se sastoji u smanjivanju iznosa osnivačkog kapitala, gdje se kao poluga koriste društva koja obitelj izravno kontrolira. Na taj način objašnjavaju širu primjenu piramidalnih struktura u odnosu na model gdje se isti separacijski efekat postiže primjenom dionica koje daju različito pravo glasa. Autori upućuju i na normativne implikacije ovih praksi koje su „dobre za obitelj“, ali ne pridonose u istoj mjeri društvenoj dobrobiti. Stoga ih se često optužuje da time dovode do neučinkovite alokacije korporativne kontrole kroz pravila o nasljeđivanju, ${ }^{67}$ štete razvoju (eksternog) tržišta kapitala ${ }^{68}$ te lobiraju za regulaciju koja koči financijski razvoj. ${ }^{69}$

U piramidalnim strukturama neproporcionalan odnos upravljačkih prava i udjela u temeljnom kapitalu veći je nego kod primjene ostalih načina odstupanja od načela ,jedna dionica - jedan glas“. Piramidalne strukture mogu se kombinirati s izdavanjem dionica koje daju različita prava glasa ili i s ostalim mehanizmima odstupanja od načela ,jedna dionica - jedan glas““. To otežava izračunavanje utjecaja neproporcionalnog odnosa upravljačkih prava i udjela u temeljnom kapitalu društva, pogotovo ako objava podataka u svezi s držanjem blokova glasačkih prava nije transparentna. Takvi su slučajevi u Izvješću Visoke skupine stručnjaka za pravo društava iz 2002. godine 70 $^{70}$ definiraju kao abusive pyramids.

65 La Porta, R., Lopez-de-Silanes, F., Shleifer, A., Corporate ownership around the world, Journal of Finance, vol. 54., 1999., str. 471-517.

66 Almeida, H., Wolfenzon, D., op. cit., str. 2637-2681.

67 Morck, R., Stangeland, D., Yeung, B., Inherited wealth, corporate control and economic growth: The Canadian disease, 2000., str. 41, dostupno na: https://www.nber.org/papers/w6814.pdf.

68 Almeida, H., Wolfenzon, D., op. cit., str. 2637-2681.

69 O tome više vidi: Raghuram, G., R., Zingales, L., The great reversals: The politics of financial development in the 20th Century, Journal of Financial Economics, vol. 69., 2003., str. 5-50. Isto: Morck, R., Yeung, B., Family control and the rent-seeking society, Entrepreneurship: Theory and Practice, vol. 28, 2004., str. 391-409.

70 Report of the High Level Group of Company Law Experts on Issues Related to Takeover Bids, Brussels, 10 January 2002, dostupno na: http://ec.europa.eu/internal_market/company/docs/ takeoverbids/2002-01-hlg-report_en.pdf, str. 3. 


\subsection{Uzajamni udjeli}

Kod uzajamnih se udjela (engl. cross-shareholdings) radi o slučaju kada društvo A drži dionice u društvu $\mathrm{B}$, a društvo $\mathrm{B}$ drži dionice u društvu $\mathrm{A}$, kao i kada društvo $\mathrm{A}$ drži dionice u društvu $\mathrm{B}$, društvo $\mathrm{B}$ drži dionice $u$ društvu $\mathrm{C}$, a društvo $\mathrm{C}$ drži dionice $\mathrm{u}$ društvu A. ${ }^{71}$ Najviše se primjenjuje u Švedskoj (25 \% društava). Najčešće ograničenje kome je podvrgnuta primjena uzajamnih udjela je oduzimanje prava glasa prilikom prelaska određenog praga koji u Italiji iznosi $2 \%$, Belgiji, Španjolskoj, Francuskoj i Finskoj $10 \%$ te Njemačkoj, Japanu i Mađarskoj $25 \%$.

U hrvatskom zakonodavstvu izričito se uređuju društva s uzajamnim udjelima. Hrvatski zakonodavac razlikuje obično i kvalificirano uzajamno sudjelovanje. O običnom uzajamnom sudjelovanju riječ je kad jedno društvo sudjeluje u drugome s više od četvrtine udjela, a društvo ne može ostvarivati prevladavajući utjecaj, dok kod kvalificiranog uzajamnog sudjelovanja postoji odnos ovisnosti društva.

Obično uzajamno sudjelovanje uređeno je odredbom članka 511. ZTD-a sukladno kojoj, ako društvo kapitala i neko drugo takvo društvo imaju udjele jedno u drugome, mogu, ako im je poznato takvo sudjelovanje u udjelima, odnosno ako im je ono priopćeno u skladu s odredbom članka 478. ZTD-a, koristiti prava iz udjela koja jedno društvo ima u drugome, najviše do četvrtine svih udjela drugoga društva. ${ }^{72}$ Ako je društvo sa svoje strane poslalo drugome društvu obavijest o uzajamnim udjelima, propisano ograničenje ne vrijedi prije nego što ono primi takvu obavijest od drugoga društva, odnosno prije nego što mu postojanje međusobnih udjela postane poznato. Dalje je propisana obveza društvima s uzajamnim udjelima o obvezi međusobnoga obavještavanja o visini vlastitoga udjela i o svim nastalim promjenama koje su s time u vezi.

Kvalificirano uzajamno sudjelovanje uređuje odredba članka 477. ZTD-a koja izričito propisuje da su društva s uzajamnim udjelima društva kapitala sa sjedištem u Republici Hrvatskoj koja su povezana tako da svako društvo ima više od četvrtine udjela u drugome društvu. ${ }^{73}$ Hrvatski zakonodavac propisuje neoborivu pretpostavku postojanja odnosa ovisnosti ako se radi o društvima povezanima uzajamnim udjelima, a ispunjene su pretpostavke za postojanje većinskog sudjelovanja jednog društva $u$ drugom. Time je zakonodavac odstupio od članka 475. st. 2. gdje je propisao oborivu pretpostavku za postojanje odnosa ovisnosti. ${ }^{74}$

Temeljem odredbe članka 478. st. 1. ZTD-a čim jedno društvo stekne više od četvrtine dionica u drugom dioničkom društvu sa sjedištem u Republici Hrvatskoj

71 U doktrini se ovakvo sudjelovanje naziva prstenasto ili cirkularno sudjelovanje (njem. ringformige oder zirkulare Beteiligung, engl. circular ownership links). Jurić, D., Transparentnost statusnih i financijskih odnosa povezanih društava Zbornik Pravnog fakulteta Sveučilišta u Rijeci, vol. 27, 2/2006, str. 946.

72 To ne vrijedi za pravo da se steknu nove dionice pri povećanju temeljnoga kapitala iz sredstava društva.

73 Za utvrđenje pripada li nekome društvu više od četvrtine udjela u drugome društvu primjenjuju se odredbe članka 474. stavka 2. i 4. ZTD-a.

74 Jurić, D., Hrvatsko pravo povezanih društava s prikazom njemačkog, francuskog i engleskog prava (magistarski rad), Pravni fakultet u Rijeci, 2002., str. 30. 
mora o tomu bez odgađanja pismeno obavijestiti to društvo.$^{75}$ Odredbom članka 478. st. 3. ZTD-a određuje se da čim društvo stekne većinsko sudjelovanje u drugome društvu, sukladno članku 474. st. 1. ZTD-a, mora o tome bez odgađanja pismeno obavijestiti to društvo. Ako udio u društvu postane manji od onoga zbog kojega je postojala obveza obavještavanja, društvo se o tomu mora pismeno obavijestiti bez odgađanja. Društvo kojemu je dostavljena obavijest mora sudjelovanje, o kojemu je obaviješteno, bez odgađanja objaviti u svome glasilu i navesti društvo koje u njemu drži dionice. Na isti se način i u istome roku mora objaviti i da više nema sudjelovanja. Društvo koje je steklo više od četvrtine dionica u drugom dioničkom društvu sa sjedištem u Republici Hrvatskoj, društvo koje je o njemu ovisno, kao i onaj tko drži dionice i udjele za račun tih društava ne mogu ostvarivati prava iz dionica u drugome društvu sve dok ga o tomu ne obavijeste.

\subsection{Problemi izračuna broja glasova kod piramidalnih struktura $i$ uzajamnih udjela}

U slučaju postojanja piramidalnih struktura i uzajamnih udjela pojavljuje se problematika izračunavanja konačnog broja glasova koje pripadaju pojedinom dioničaru.

Kod piramida uobičajena metoda za izračunavanje konačnog broja glasova je primjena tzv. načela najslabije karike (engl. weakest-link principle), prema kojem ako dioničar drži dionicu s određenim brojem glasova (x) u društvu A koje drži dionice s određenim brojem glasova $(\mathrm{y}) \mathrm{u}$ društvu $\mathrm{B}$, pretpostavlja se da ovaj dioničar drži minimum x i y broja glasova u društvu B. ${ }^{76}$ Ova je metoda izložena brojnim kritikama. Tako se mogu usporediti dva slučaja. U prvom slučaju dioničar drži $26 \%$ glasačkih prava u društvu A, koje drži $25 \%$ glasačkih prava u društvu B. U drugom slučaju dioničar drži 90 \% glasačkih prava u društvu C koje drži 25\% glasačkih prava u društvu D. U oba se slučaja, primjenom načela najslabije karike, dolazi do istoga rezultata, međutim, utjecaj kojega de facto ostvaruje dioničar u prvom i u drugom slučaju znatno se razlikuje. Ujedno, daljnji problem koji se pojavljuje kod primjene načela najslabije karike jest postojanje dva ili više dioničara koji zajednički ostvaruju kontrolu. ${ }^{77}$ Tako primjerice u društvu X dioničar A drži 17 \% glasačkih prava, dok

75 Za utvrđenje ima li društvo više od četvrtine dionica primjenjuju se odredbe članka 474. stavka 2. i 4. ZTD-a. Ujedno među dionice o čijem se stjecanju mora obavijestiti drugo društvo pripadaju i dionice i udjeli 1. koje društvo, od njega ovisno društvo ili netko tko ih drži za njegov račun ili za račun društva koje je od njega ovisno može tražiti da mu se prenesu, 2. za čije preuzimanje je u obvezi društvo, neko društvo koje je ovisno o njemu ili netko tko djeluje za račun društva ili društva koje je o njemu ovisno.

76 U piramidama se imovinska prava množe. Ako dioničar drži određeni broj dionica (x) u društvu A koje drži određeni broj dionica $u$ društvu $\mathrm{B}$ tada je taj dioničar ovlašten na $\mathrm{x}^{*} \mathrm{y}$ imovinskih prava u društvu B. O tome više vidi kod Adams, R., Ferreira, D., One Share-One Vote: The Empirical Evidence, Finance Working Paper no. 177/2007, str. 7, dostupno na: http://ssrn.com/ abstract_id $=987488$ (posjećeno 14.1.2019.).

77 Edwards, J., Weichenrieder, A., Control Rights, Pyramids, and the Measurement of Ownership Concentration, dostupno na: http://ssrn.com/abstract=1354580, str. 6 (posjećeno 20.11.2011.), dolaze do apsurdnih rezultata u izračunavanju postotka držanja glasačkih prava primjenom 
dioničar B drži 33 \% glasačkih prava. Struktura dioničara društva A je takva da 40 $\%$ drži jedan dioničar (dioničar C), dok tri dioničara drže po $20 \%$ glasačkih prava. Dioničarska struktura dioničara društva $\mathrm{B}$ je takva da jedan dioničar drži $10 \%$ dionica (dioničar D), dok je ostala dioničarska struktura disperzirana. Primjenom načela najslabije karike dolazimo do rezultata da dioničar C drži $17 \%$ glasačkih prava u društvu X, dok dioničar D drži $10 \%$ glasačkih prava u društvu X. ${ }^{78}$

Alternativna metoda za izračunavanje broja glasova je uzimanje u obzir samo broja glasova u posljednjem društvu (društvu B) sve dok dioničar drži dionice u društvu A. Ovdje je riječ o načelu posljednje karike. ${ }^{79}$

Pokazano na primjeru dioničkog društva Volkswagen $A G, 2007$. godine Porsche Family je držao 100 \% glasačkih prava u uvrštenom društvu Porsche $A G$ koje je držalo 25,1 \% glasačkih prava u Volkswagenu (minimum od 100 \% i 25,1 \%). Sukladno načelu posljednje karike pravo glasa koje je držao Porsche Family u Volkswagenu također je $25,1 \%$. Kao što je prikazano na navedenom primjeru, oba pristupa daju isti rezultat. Međutim, oni se isto tako mogu i uvelike razlikovati, npr. ako društvo A drži $25 \%$ prava glasa u društvu B koje drži $100 \%$ prava glasa u društvu C, primjenjujući načelo najslabije karike dolazi se do rezultata od $25 \%$ prava glasa, dok se primjenjujući načelo posljednje karike dolazi do rezultata od $100 \%$ prava glasa.

Pitanje izračunavanja broja glasova koji pripadaju pojedinom dioničaru javlja se i kod postojanja uzajamnih udjela. Iako je to relativno jednostavno kada dva društva drže dionice jedno u drugome, problem je kompleksniji kada je riječ o tri ili više društava.

U hrvatskom pravu za izračunavanje broja glasova kod povezanih društava primjenjuje se članak 474. ZTD-a gdje je propisano da se broj glasova koji pripada nekome društvu određuje prema odnosu broja glasova koje ono može koristiti na temelju dionica koje mu pripadaju, prema ukupnom broju svih glasova. Od ukupnog broja glasova moraju se odbiti glasovi koji pripadaju po vlastitim dionicama i dionicama koje netko drugi drži za račun toga društva. Iz navedene formulacije proizlazi da se ne isključuju glasovi temeljeni na udjelima koje drži društvo koje je ovisno u odnosu na društvo u kojem se izračunava većinsko sudjelovanje. Međutim, člancima 235. i 237. ZTD-a iz tih se udjela ne bi moglo ostvarivati pravo glasa. Primjerice, ako je društvo A vladajuće u odnosu na društvo $\mathrm{B}$, a društvo B drži ujedno i $15 \%$ udjela u društvu A, tada se glasovi koji se temelje na tih $15 \%$ udjela ne odbijaju od ukupnog broja glasova. Ako bi društvo C imalo $45 \%$ udjela u društvu A, ono ako se uzimaju u obzir svi glasovi, ima svega 45 \% glasova, dakle nema većinsko sudjelovanje. No, budući

načela najslabije karike, primjerice dolaze do rezultata da se drži $165 \%$ glasačkih prava u društvu.

78 Edwards, J., Weichenrieder, A. J., How Weak is the Weakest-Link Principle? On the Measurement of Firm Owners' Control Rights (August 2004). CESifo Working Paper Series no. 1255, str. 9, dostupno na: https://ssrn.com/abstract=591902 (14.1.2019.), navode primjer društva Linotype-Hell, ističući nedostatke u primjeni načela najslabije karike.

79 Renneboog, L., Ownership, Managerial Control and the Governance of Companies Listed on the Brussels Stock Exchange (July 1996), Working Paper 9635, dostupno na: https://ssrn. com/abstract $=2115$, str. 14 , ističe da $56 \%$ uvrštenih belgijskih društava u izračunavanju broja glasova primjenjuje načelo posljednje karike (engl. ultimate shareholder criterion). 
da kod glasovanja, na temelju članaka 235. i 237. ZTD-a društvo B ne bi moglo glasovati s $15 \%$ glasova, proizlazi da bi se ukupno moglo glasovati s $85 \%$ glasova u odnosu na ukupni broj glasova iz čega proizlazi da bi društvo $\mathrm{C}$ kod glasovanja imalo sada ukupno $52 \%$ glasova, a ne više svega $45 \%{ }^{80}$

Na temelju odredbe članka 10. stavka 1(c) Direktive o ponudama za preuzimanje države članice su dužne osigurati da ciljna društva objave detaljne informacije o bitnom izravnom ili neizravnom sudjelovanju u temeljnom kapitalu, uključivši neizravno sudjelovanje u temeljnom kapitalu putem piramidalnih struktura i uzajamnih udjela, prema članku 85. Direktive 2001/34/EZ. Nužno je istaknuti da piramidalne strukture nisu obuhvaćene primjenom pravila proboja, što je izričito istaknuto u Izvješću visoke skupine stručnjaka za pravo društava. ${ }^{81}$ Pravilo proboja se ne primjenjuje niti na uzajamne udjele (engl. cross-shareholdings).

Sukladno odredbi članka 272.p. stavka 1.t. d. ZTD-a nadzorni, odnosno upravni odbor društva dionicama kojeg se trguje na uređenom tržištu dužni su osigurati da uprava, odnosno izvršni direktori društva u posebnom odjeljku godišnjeg izvješća o stanju društva navedu podatke o značajnim neposrednim i posrednim imateljima dionica u društvu, uključujući posredno držanje dionica u piramidalnim strukturama i uzajamnim udjelima.

Svakako valja spomenuti i odredbe Kodeksa korporativnog upravljanja koji su izradili HANFA i Zagrebačka burza, ${ }^{82}$ a koji se primjenjuje od 1. siječnja 2011. godine, koji u pravilu 2.5.2. Uzajamno dioničarstvo nameće obvezu društvu javno objavljivati podatke o uzajamnom dioničarstvu. Pritom će se smatrati da između dva dionička društva postoji odnos uzajamnog dioničarstva kada su ta društva povezana na način da svako od njih ima više od $5 \%$ udjela u temeljnom kapitalu u drugom društvu.

\section{ZAKLJUČNE NAPOMENE}

Uzajamno držanje udjela kao metoda pojačanja kontrole, odnosno odstupanja od načela proporcionalnosti, iako je svrstana u metode koje su nastale na tržištu kapitala, bilježi pad značenja u Europi, kao i u Aziji, gdje je bila tradicionalno najzastupljenija.$^{83}$ Društva s uzajamnim udjelima bila su nekad vrlo česta u njemačkoj populaciji uvrštenih društava, gdje su financijske institucije držale udjele/dionice u

80 Primjer je preuzet iz Gorenc, V., Slakoper, Z., Filipović, V., Brkanić, V., Komentar Zakona o trgovačkim društvima, RRiF, Zagreb, 2004., str. 798.

81 Report of the High Level Group of Company Law Experts on Issues Related to Takeover Bids, Brussels, 10 January 2002, dostupno na: http://ec.europa.eu/internal_market/company/docs/ takeoverbids/2002-01-hlg-report_en.pdf, str. 6.

82 Tekst novog Kodeksa korporativnog upravljanja dostupan je na: http://www.ripe.hanfa.hr/hr/ vijesti/objavljen-novi-kodeks-korporativnog-upravljanja/.

83 Tako, primjerice, japanska uvrštena društva ubrzano bježe od tradicionalne prakse crossshareholdinga koja postoji između povezanih društava koja jedno u drugom drže udjele u cilju "to solidify their business ties". Oshino, S., Japan's cross-held shares fall below $10 \%$ of all holdings, Nikkei Asian Review, 16.07. 2017., dostupno na: https:/asia.nikkei.com/Business/ Japan-s-cross-held-shares-fall-below-10-of-all-holdings2 (posjećeno: 17.01.2019.). 
industrijskim društvima, što je dovodilo do toga da su u nadzornim odborima bili zastupljeni predstavnici banaka. ${ }^{84}$ Držanje uzajamnih udjela garantiralo je stabilnu korporativnu strukturu i kontinuitet u upravljanju. No, ipak se radi o pojavnom obliku koji ograničava pristup tržištu „korporativne kontrole“, s obzirom na to da su to ipak bila uvrštena društva. Iako se situacija u Njemačkoj još u prvom desetljeću ovog tisućljeća počela mijenjati, jer su banke prodale svoje blokove dionica industriji, zastupljenost bankara $\mathrm{u}$ članstvu nadzornih odbora je i dalje ostala vrlo velika. ${ }^{85}$ Banke su osim kroz članstvo u nadzornom odboru, vršile utjecaj i kao glasački aktivni skrbnici dionica iako su te dionice bile dio tržišnog free-floata. U upravljanju društvom stvorilo se ozračje gdje dominira prijateljsko, ali ujedno i neprobojno okruženje, gdje se strategija društva razvija prvenstveno kroz suradnju uprave i nadzornog odbora, dok su odnosi s ulagateljima manje važan cilj korporativne kulture. No, ta je strategija s jačanjem tržišta kapitala postala stvar prošlosti. Što se tiče empirijskih pokazatelja jasno je da su uz društva sa uzajamnim udjelima piramidalne strukture i dalje dosta zastupljen mehanizam pojačanja kontrole, osobito kod obiteljskih uvrštenih društava.

Sasvim praktično pitanje ovih mehanizama za pojačanje kontrole pitanje je načina računanja glasova i duž piramidalne kaskade i kod uzajamnog držanja udjela, s obzirom na to da se glasačka snaga kumulira. Ako je u piramidalnu strukturu ili u društva s uzajamnim udjelima uključeno ciljno društvo (potencijalni objekt preuzimanja), način računanja itekako utječe na procjenu je li u tom društvu došlo do promjene u glasačkoj kontroli, ${ }^{86}$ jer ako jest, navedeno bi bilo okidač za dužnost objave ponude za preuzimanje dionica tog uvrštenog društva. Zbog toga ima smisla što se ovi mehanizmi pojačanja kontrole tumače kao svojevrsne odvraćajuće protupreuzimateljske mjere, pa je cilj da podatci o tomu postoje i da su dostupni ulagateljskoj javnosti.

Ako promatramo je li došlo do promjene glasačke kontrole nad ciljnim društvom koje je dio piramide ili je jedno od društava s uzajamnim udjelima valja kao ključne uzeti u obzir dvije odredbe ZPDD-a. Članak 5. stavak 4. ZPDD-a poznaje neoborivu predmnijevu zajedničkog djelovanja između društava koja su povezana u smislu odredbi ZTD-a o povezanim društvima, a prema članku 8. stavku 1. ZPDD-a glasačka prava osoba koje djeluju zajednički (a društva s uzajamnim udjelima to jesu) zbrajaju se da bi se utvrdilo je li došlo do prelaska kontrolnog praga, koji je okidač za obvezu objave ponude za preuzimanje.

Kada su u pitanju piramidalne strukture, one se mogu, ali i ne moraju uklopiti u koncept povezanih društava. Najčešće se po kaskadi piramide radi o odnosu ovisnog i vladajućeg društva ili društva koje u drugom ima većinu udjela ili većinsko pravo odlučivanja. No s obzirom na to da dionice mogu držati i fizičke osobe (članovi obitelji), odnosno entiteti koji nisu trgovačka društva (npr. obiteljski trustovi), neoboriva presumpcija zajedničkog djelovanja koja vrijedi za povezana društva i koja

84 Onetti, A., Pisoni, A., Ownership and control in Germany: Do cross-shareholdings reflect bank control on large companies?. Corporate Ownership \& Control / Corporate Ownership \& Control, vol. 6, 4/2009., str. 54-77.

85 Ibid., str. 73.

86 Zubović, A., Stjecanje glasačke kontrole nad uvrštenim društvom, Zagreb, doktorska disertacija, Zagreb, 2012., str. 1-570. 
propisuje uračunavanje glasova ne može se primijeniti u potpunosti na piramidu u kojoj osim trgovačkih društava sudjeluju i drugi entiteti. Tada je po mišljenju autorica osnova za uračunavanje glasova kriterij izravne ili neizravne kontrole koji je sadržan u članku 5. stavku 4. ZPDD-a, iako treba naglasiti da za taj kriterij ne postoji neoboriva presumpcija zajedničkog djelovanja za razliku od društava s uzajamnim udjelima. Dakle piramidalne strukture i onda kada ne udovoljavaju kriteriju iz članka 5. stavka 4. ZPDD-a (ako je u piramidu uključena fizička osoba ili entitet koji nije trgovačko društvo) mogle bi na temelju kontrole ostvariti odnos zajedničkog djelovanja koji daje osnovu za pribrajanje glasova na način kako to propisuje ZPDD. To je relevantno za preuzimateljski scenarij, a on postoji samo ako je društvo u odnosu na koje se pokušava izračunati glasačka snaga - uvršteno društvo.

Upravo zbog zahtjeva jasnoće i transparentnosti odnosa kontrole gospodarski povezanih subjekata, europski zakonodavac u članku 10. stavku 1(c) Direktive o ponudama za preuzimanje stavlja u zadatak državama članicama da osiguraju da ciljna društva objave detaljne informacije o bitnom izravnom ili neizravnom sudjelovanju u temeljnom kapitalu, uključivši neizravno sudjelovanje u temeljnom kapitalu putem piramidalnih struktura i uzajamnih udjela.

Kako niti jedan oblik ,povezanosti““ povezanih društava prema ZTD-u nije vidljiv iz sudskog registra, osim poduzetničkih ugovora, transparentnost podataka o navedenim kapitalnim povezivanjima u populaciji uvrštenih društava ima svoju normativnu podršku u odredbama ZTK-a koje obvezuju uvrštena društva da objavljuju podatke o svojoj unutrašnjoj korporativnoj strukturi (prelaskom i padom određenih glasačkih pragova, nakon što ih stjecatelji tih blokova dionica o tomu obavijeste), pa je to ujedno i jedini izvor podataka o frekvenciji takvih kapitalnih povezivanja na razini uvrštenih društava. Naime, prema ZTK-u u dužnost objave ubrajaju se i izravni i najrazličitiji načini neizravnog držanja dionica (glasačkih prava). Jedan od njih relevantan za ovu temu je onaj opisan u članku 485. stavku 5. ZTK-a, a to je takav oblik držanja kod kojeg glasačka prava drži ili može ostvarivati kontrolirano društvo neke fizičke osobe ili pravnog subjekta pa se i ti glasovi ubrajaju za potrebe izračuna broja glasova koji podliježu dužnosti objave odnosno, tzv. obavijesti o promjenama u glasačkim pravima. ${ }^{87}$ Navedeni propis svakako doprinosi transparentnosti piramidalnih struktura u populaciji uvrštenih društava, budući da po svim kaskadama piramide nisu trgovačka društva već i fizičke osobe, odnosno drugi pravni entiteti. Nije na odmet spomenuti i to da članak 457. ZTK-a ${ }^{88}$ ima i vlastitu definiciju kontroliranog društva,

87 Tako prema čl. 482. st. 1. ZTK-a fizička osoba ili pravni subjekt koji neposredno ili posredno dosegne, prijeđe ili padne ispod praga od $5 \%, 10 \%, 15 \%, 20 \%, 25 \%, 30 \%, 50 \%$ i $75 \%$ glasačkih prava u izdavatelju dionica obvezan je o takvom dosezanju, prelasku ili padu ispod praga glasačkih prava dostaviti izdavatelju i Agenciji (...), a izdavatelj je dužan tu obavijest objaviti.

88 Prema tom članku (st. 1.) kontrolirano društvo je pravni subjekt: 1. u kojem fizička osoba ili drugi pravni subjekt ima većinu glasačkih prava; 2. u kojem je fizička osoba ili drugi pravni subjekt dioničar ili član te u kojem istodobno ima pravo imenovati ili opozvati većinu članova upravnog, upravljačkog ili nadzornog organa; 3 . u kojem je fizička osoba ili drugi pravni subjekt dioničar ili član te u kojem samostalno kontrolira većinu glasačkih prava dioničara ili članova na temelju sporazuma sklopljenog s drugim dioničarima ili članovima toga pravnog subjekta ili 4. nad kojim fizička osoba ili drugi pravni subjekt može ostvarivati ili ostvaruje prevladavajući 
koji pojam je bitan za uračunavanje glasova temeljem članka 485. stavka 5. ZTK-a.

Ako se problematika piramidalnih struktura i društava s uzajamnim udjelima promatra na razini neuvrštenih društava kao instrument pojačanja ili zaključavanja kontrole, tada bi, što se tiče hrvatskoga prava, za društva s uzajamnim udjelima bila mjerodavna metodologija obračuna koju propisuje članak 474. u stavcima 2 i 4 . ZTD-a s obzirom na to da na njega upućuje članak 477. ZTD-a koji se primjenjuje na društva $\mathrm{s}$ uzajamnim udjelima. Analogno bi rješenje po mišljenju autorica trebalo primijeniti i na piramidalne strukture (koje će najčešće biti u formi odnosa vladajućeg i ovisnog društva, društva s većinskim udjelom ili većinskim pravom u odlučivanju). Naravno, situacija se usloženjuje ako se u piramidalnom odnosu ili odnosu uzajamnosti pojavljuje više društava, od kojih je svatko s drugim društvom na drugi način povezano ili se u piramidi pojavljuju entiteti koji nisu trgovačka društva, što je vrlo često slučaj kod obiteljskih društava. Treba naglasiti i to da ako je piramida visoka i zaustavlja se na pravnoj osobi koja nije trgovačko društvo nego neki drugi entitet čija unutrašnja struktura nije namijenjena transparentnom prikazivanju, potraga za osobom koja ima stvarnu korporativnu kontrolu izmiče očima javnosti. ${ }^{89}$ To je posebno relevantno za uvrštena društva kod kojih postoji interes javnosti i tržišta kapitala za utvrđivanjem osoba koje imaju stvarnu kontrolu, pa zbog toga i postoji dužnost uvrštenog društva da objavljuje podatke o svojoj korporativnoj strukturi.

Iako se piramidalne strukture per se ne mogu osuditi, osim ako se ne koriste za ispunjenje nekih nelegitimnih ciljeva (porezne evazije i sl.), nameće se konačni zaključak da ova dva mehanizma pojačanja kontrole barem u odnosu na uvrštena društva treba učiniti vidljivima, za što postoji zakonsko uređenje iz ZTK-a koje podupire i Kodeks korporacijskog upravljanja. Zakonodavcu svakako uvijek ostaje na raspolaganju manevarski prostor da mjerama porezne politike i promjenom poreznih propisa utječe na jačanje ili slabljenje piramida, ocijeni li da su one abuzivne, no takav bi regulatorni korak morao imati svoju empirijsku podlogu.

\section{LITERATURA}

1. Adams, Renée, Ferreira, Daniel, One Share-One Vote: The Empirical Evidence, Finance Working Paper No. 177/2007, dostupno na http://ssrn.com/abstract_id=987488 (posjećeno 14.1.2019.)

2. Almeida, Heitor, Wolfenzon, Daniel, A Theory of Pyramidal Ownership and Family Business Groups, Journal of Finance, vol. 61, 2006., str. 2637-2681.

3. Aluchna, Maria, Kuszewski, Tomasz, Pyramidal structures: The evidence from Poland, South African Journal of Business Management, vol 49, 1/2018, dostupno na; https:// sajbm.org/index.php/sajbm/article/view/1/802 (posjećeno 10. 1. 2019).

4. Bajo, Anto, Zuber, Lana, Primorac, Marko, Uspješnost financijskog poslovanja poduzeća (trgovačkih društava) u vlasništvu države, Fiscus, br. 5/2017, dostupno na: http://www.ijf. hr/upload/files/file/FISCUS/5.pdf (posjećeno 16. 1. 2019.)

utjecaj ili kontrolu. U st. 2. istog članka se fizička osoba ili drugi pravni subjekt iz prethodnog smatra vladajućom osobom.

89 Ranije navedeni primjer ustroja Maxwell Communication gdje je sve ključne odluke donosio obiteljski trust. 
5. Bank, Steven A., Cheffins, Brian R., The Corporate Pyramid Fable, 84 Bus. Hist. Rev. 435, 443-45 (2010).

6. Bank, Steven A., When We Taxed the Pyramids, 41 Florida State University Law Review. vol 41, 1/2013, http://ir.law.fsu.edu/lr/vol41/iss1/3 str. 40-41. (posjećeno 16. 1. 2019.)

7. Bennedsen, Morten, Nielsen, Kasper Meisner, The Principle of Proportional Ownership, Investor Protection and Firm Value in Western Europe (October 2006). ECGI - Finance Working Paper No. 134/2006. Available at SSRN: https://ssrn.com/abstract=941054 (posjećeno 16. 1. 2019.)

8. Bianchi, Marcello, Bianco, Magda, Italian Corporate Governance in the Last 15 Years: From Pyramids to Coalitions? (November 2006). ECGI - Finance Working Paper No. 144/2006. Available at SSRN: https://ssrn.com/abstract=952147 (posjećeno 16. 1. 2019.)

9. Burkart, Mike, Lee, Samuel, The One Share - One Vote Debate: A Theoretical Perspective Finance Working Paper No. 176/2007, May 2007, http://ssrn.com/abstract_id=987486 dostupno na: www.ecgi.org/wp str. 33. (posjećeno 16. 1. 2019.)

10. Carlin, Wendy, Mayer, Colin, Finance, investment and growth, Journal of Financial Economics, vol. 69, 1/2003, str. 191-226.

11. Castañer, Xavier, Kavadis, Nikolaos, Does good corporate governance prevent bad strategies? An empirical analysis of non-value creating financial diversification in French companies, 2000-2006, Strategic Management Journal, vol. 34, 7/2013, str. 863-876.

12. Combs, James, J., Commentary: The servant, the parasite, and the enigma: A tale of three ownership structures and their affiliate directors, Entrepreneurship Theory and Practice, vol. 32., 6/2008, str. 1027-1033.

13. Culinović-Herc, Edita, Grković,Nikolina. Impact of the Madoff Scandal on the Forthcoming UCITS V Directive, u: V. Kandžija, A. Kumar, (ur.), Economic integrations, competition and cooperation: Accession of the Western Balkan Countries to the EU, Ekonomski fakultet u Rijeci, Rijeka, 2013, str. 168-182.

14. Čulinović-Herc, Edita, Zubović, Antonija, Cash Settled Derivatives and Their Role in Companies' Takeovers, u Bodiroga-Vukobrat, Nada, Rodin, Siniša, Sander, Gerald G., (eds.), Europeanization and Globalization, New Europe - Old Values?, Reform and Perseverance, vol. 1, Springer, 2016., str. 235-267.

15. Čulinović-Herc, Edita, Zubović, Antonija, Is there a need for a revision of the control threshold in Croatian takeover law?, SGEM 2016 Conference Proceedings on Political Sciences, Law, Finance, Economics \& Tourism, Volume II, Book 2, Bulgaria, 2016, str. 669-676.

16. Čulinović-Herc, Edita, Zubović, Antonija, Tackling Empty Voting in EU - Shareholders' Rights Directive and Revised Transparency Directive, Croatian Yearbook of European Law and Policy, vol. 11, 2015., str. 133-160.

17. Čulinović-Herc, Edita., Grković, Nikolina. Odjeci financijskog skandala Madoff u parničnoj praksi zemalja članica Europske unije na primjeru fonda Luxalpha SICAV. Zbornik Pravnog fakulteta u Zagrebu, vol. 63, 3-4/2013, str. 593-615. https://hrcak.srce. hr/109721 (posjećeno 16. 1. 2019.)

18. Denis, Diane K., McConnell, John J., "International Corporate Governance" (2001). Purdue CIBER Working Papers. Paper 17, http://docs.lib.purdue.edu/ciberwp/17, 1-56.

19. Edwards, Jeremy, Weichenrieder, Alfons J., How Weak is the Weakest-Link Principle? On the Measurement of Firm Owners' Control Rights (August 2004). CESifo Working Paper Series No. 1255., dostupno na https://ssrn.com/abstract=591902 (14.1.2019.)

20. Edwards, Jeremy, Weichenrieder, Alfons, Control Rights, Pyramids, and the Measurement of Ownership Concentration, http://ssrn.com/abstract=1354580, str. 6. (posjećeno 20.11.2011.)

21. Ehrhardt, Olaf, Nowak, Eric, Private Benefits of Control in Founding-Family Owned Firms: An Analysis of the Dynamics of Disproportionate Ownership and Control in Family Firm IPOs (July 1, 2015). Available at SSRN: https://ssrn.com/abstract=423506 
22. Ferrarini, Guido, One Share - One Vote: A European Rule? (January 2006). ECGI - Law Working Paper No. 58/2006., str. 16., dostupno na https://ssrn.com/abstract=875620 (posjećeno 16. 1. 2019.)

23. Franks, Julian, Colin Mayer, Ownership and control of German corporations, Review of Financial Studies, vol. 14, 2001., str. 943-977. Isto: CEPR Discussion Paper No. 2898, dostupno na https://ssrn.com/abstract $=279387$ (posjećeno 10. 1. 2019.).

24. Gadhoum, Yoser, Power of Ultimate Controlling Owners: a Survey of Canadian Landscape, Journal of Management Governance, 10/2006, str. 179-204.

25. Geens, Koen, Clottens, Carl, One Share - One Vote: Fairness, Efficiency and (the Case for) EU Harmonisation Revisited, u: Hopt, Klaus, J., Geens, Koen, (eds.) The European Company Law Action Plan Revisited, Reassessment of the 2003 priorities of the European Commission, Leuven University Press, 2010, dostupno na http://ssrn.com/ abstract=1547842; (posjećeno 14.1.2019.).

26. Ginglinger, Edith, Hamon, Jacques, Ownership, Control and Market Liquidity (June 1, 2012). Finance, 2012, 33, 2, str. 61-99. Dostupno na https://ssrn.com/abstract=2097795, str. 10.

27. Goergen, Marc., Martynova, Marina, Renneboog, Luc. Corporate Governance Convergence: Evidence From Takeover Regulation Reforms in Europe, Oxford Review of Economic Policy, Vol. 21, br. 2, str. 243-268.

28. Gorenc, Vilim, Slakoper, Zvonimir, Filipović, Vladimir, Brkanić, Vlado, Komentar Zakona o trgovačkim društvima, RRiF, Zagreb, 2004, str. 798.

29. Hu, Henry, T. C., Black, Bernard, Empty Voting and Hidden (Morphable) Ownership: Taxonomy, Implications, and Reforms, The Business Lawyer, vol. 61, br. 3/2006., str. 1011-1070.

30. Hu, Henry, T. C., Black, Bernard, The New Vote Buying: Empty Voting and Hidden (Morphable) Ownership, Southern California Law Review, vol. 79, 2006., str. 811.

31. Institutional Shareholder Services, ECGI, Shearman \& Sterling LLP, Proportionality between ownership and control in EU listed companies: External study commissioned by the European Commission, Report on the Proportionality Principle in the European Union, 18 May 2007, str. 1-216. Dostupno na http://www.ecgi.org/osov/documents/final_ report_en.pdf (posjećeno 16. 1. 2019.)

32. Jurić, Dionis, Hrvatsko pravo povezanih društava s prikazom njemačkog, francuskog i engleskog prava (magistarski rad), Pravni fakultet u Rijeci, 2002, str. 1-163

33. Jurić, Dionis, Transparentnost statusnih i financijskih odnosa povezanih društava Zbornik Pravnog fakulteta Sveučilišta u Rijeci v. 27, 2/2006, str. 939-984.

34. Jurić, Dionis, Uloga revizora u dioničkom društvu, Zbornik Pravnog fakulteta Sveučilišta u Rijeci, vol. 25, 1/2004, str. 323-352.

35. Jurić, Dionis, Zubović, Antonija, Protupreuzimateljske mjere i položaj uprave ciljnog društva, Zbornik Pravnog fakulteta Sveučilišta u Rijeci, vol. 30, 1/2009, str. 291-331.

36. Khachaturyan, Arman, The One-Share-One-Vote Controversy in the EU, ECMI Paper No. 1/2006, August 2006, str. 11.-12., dostupno na http://ssrn.com/abstract=908215 (posjećeno 14.1.2019.).

37. Kodeks korporativnog upravljanja http://www.ripe.hanfa.hr/hr/vijesti/objavljen-novikodeks-korporativnog-upravljanja/.

38. La Porta, Rafael, Florencio Lopez-de-Silanes, Andrei Shleifer, Corporate ownership around the world, Journal of Finance, vol. 54, 1999., str. 471-517.

39. Masulis, Ronald W., Pham, Peter Kien, Zein, Jason, Family Business Groups around the World: Financing Advantages, Control Motivations and Organizational Choices (April 21, 2011). Review of Financial Studies, ECGI - Finance Working Paper No. 240/2009. Dostupno na https://ssrn.com/abstract=1363878, str. 3., (posjećeno 10. 1. 2019.) 
40. McCarroll, Thomas. Scandal Maxwell's Plummet, Time Magazine, June 24, 2001, dostupno na stranici: http://content.time.com/time/magazine/article/0,9171,156074,00. html (posjećeno 16. 1. 2019.)

41. Michiels, Anneleen, Vincent, Molly, Financing Decisions in Family Businesses: A Review and Suggestions for Developing the Field, Family Business Review, Vol. 30, br. 4, 2017., str. 369-399. https://journals.sagepub.com/doi/ abs/10.1177/0894486517736958?journalCode=fbra. (posjećeno 10. 1. 2019.)

42. Morck, Randall, A history of corporate governance around the world: Family business groups to professional managers, University of Chicago Press, 2005.,

43. Morck, Randall, and Bernard Yeung, 2004, Family control and the rent-seeking society, Entrepreneurship: Theory and Practice 28, str. 391-409.

44. Morck, Randall, David Stangeland, and Bernard Yeung, 2000, Inherited wealth, corporate control and economic growth: The Canadian disease, str. 41, dostupno na: https://www. nber.org/papers/w6814.pdf

45. Morck, Randall, How to Eliminate Pyramidal Business Groups: The Double Taxation of Intercorporate Dividends and Other Incisive Uses of Tax Policy, 19 TAX POL'Y \& ECON. 135, 136 (2005).

46. Morck, Randall, The riddle of the great pyramids, u: Colpan, A. M., Hikino, T., Lincoln, J.R. (eds.), The Oxford Handbook of Business Groups, 2009., str. 602-628.

47. Onetti, Alberto, Pisoni, Alessia. Ownership and control in Germany: Do crossshareholdings reflect bank control on large companies?. Corporate Ownership \& Control / Corporate Ownership \& Control / Vol.6, 4/2009, str. 54-77

48. Oshino, Shinya, Japan's cross-held shares fall below $10 \%$ of all holdings, Nikkei Asian Review, 16.07. 2017., dostupno na: https://asia.nikkei.com/Business/Japan-s-cross-heldshares-fall-below-10-of-all-holdings2 (posjećeno: 17.01.2019.)

49. Public Utility Holding Company Act of 1935, Pub. L. No. 74-333,49 Stat. 803.

50. Rajan, Raghuram G., Zingales, Luigi, The great reversals: The politics of financial development in the 20th Century, Journal of Financial Economics 69, 2003, 5-50.

51. Renneboog, Luc, Ownership, Managerial Control and the Governance of Companies Listed on the Brussels Stock Exchange (July 1996), Working Paper 9635, dostupno na https://ssrn.com/abstract $=2115$

52. Report of the High Level Group of Company Law Experts on Issues Related to Takeover Bids, Brussels, 10 January 2002, dostupno na http://ec.europa.eu/internal_market/ company/docs/takeoverbids/2002-01-hlg-report en.pdf, str. 3.

53. Ringe Wolf-Georg, Hedge Funds and Risk-Decoupling: The Empty Voting Problem in the European Union, Oxford Legal Studies Research Paper No 52, 2012, dostupno na http:// ssrn.com/abstract=2135489 (posjećeno 16. 1. 2019.)

54. Ringe, Wolf-Georg, Deviations from Ownership-Control Proportionality-Economic Protectionism Revisited, u knjizi Bernitz, U., Ringe, Wolf-Georg (eds), Company Law and Economic Protectionism, Oxford University Press, 2010., str. 221.

55. Shleifer, Andrei., Vishny, Robert, W., A survey of corporate governance, Journal of Finance, vol. 52, 2/1997., str. 737-783.,

56. Shyu, Yih-Wen, Lee, Chun I., Excess Control Rights and Debt Maturity Structure in Family-Controlled Firms, Corporate Governance, An International Review, Vol. 17., br. 5/2009., str. 611-628. https://onlinelibrary.wiley.com/doi/abs/10.1111/j.14678683.2009.00755.x (posjećeno 10. 1. 2019.)

57. Stijn, Claessens, Djankov, Simeon, Lang, Larry H.P., The separation of ownership and control in East Asian Corporations, Journal of Financial Economics, vol. 58., str. 81-112.

58. Uhlaner, Lorraine M., Family Business and Corporate Governance, u: Wrihgt, M., Siegel, D. Keasey., Filatochev, I. The Oxford Handbook of Corporate Governance, OUP, 2013., str. 389. 
59. Van Essen, M., Carney, Michael., Gedajlovic, Eric., Heugens, Pursey, How does family control influence firm strategy and performance? A meta-analysis of US publicly listed firms, Corporate Governance: An International Review, vol. 23, 1/2015., str. 3-24.,

60. Van Essen, Mark, Heugens, Pursey, Van Oosterhout, H., Otten, J., An institution-based view of executive compensation: A multilevel meta-analytic test, Journal of International Business Studies, vol. 43, 3/2012, str. 396-423.

61. Villalonga, Belen, Amit, Raphael H., How are U.S. Family Firms Controlled? (July 1, 2007). European Corporate Governance Institute (ECGI) - Finance Working Paper No. 131/2006, dostupno na: https://ssrn.com/abstract=891004 (posjećeno 10. 1. 2019.)

62. Villalonga., Belen, Amit., Raphael. How Do Family Ownership, Control and Management Affect Firm Value? Journal of Financial Economics, Volume 80, Issue 2, May 2006, str. 385-417.

63. Zattoni, Alessandro., The structure of corporate groups: The Italian case, Corporate Governance, vol. 7, 1/1999., str. 38-48.

64. Zubović, Antonija, Stjecanje glasačke kontrole nad uvrštenim društvom, Zagreb, doktorska disertacija, 2012., str. 1-570. 


\author{
Antonija Zubović* \\ Edita Čulinović-Herc**
}

Summary

\title{
PYRAMIDAL STRUCTURES AND CROSS- SHAREHOLDING - MECHANISMS FOR DEVIATION FROM THE PRICIPLE "ONE SHARE - ONE VOTE"
}

Shares in joint stock companies may sometimes carry unequal voting rights or other mechanisms of strengthening control (control enhancing mechanisms: CEM), such as pyramidal structures. All those represent a deviation from the principle of proportionality. The CEMs, and among them, especially widely used pyramidal structures, play important role in corporate takeovers. In this paper, after the taxonomy of the CEMs is provided, special attention is ddevoted to those that are widely used on the capital market, i.e. pyramidal structures and companies that hold each other's shares (cross-shareholding). Before going into detailed analysis into each of the two, the paper investigates how those particular CEM's generally might affect behaviour of (minor and major) shareholders and board members, in case when the target company is experiencing voluntary or hostile takeover bid and whether the behaviour of mentioned stakeholders differs in companies with dispersed or concentrated ownership. Empirical data relevant for CEMs in some European countries are also presented and analyzed. In last chapter special attention is devoted to problem of calculation of the voting power when pyramidal structures and cross-sharegoldings are used, followed by authors' final remarks.

Keywords: pyramidal structure; cross-shareholding; deviation from proportionality principle; control enhancing mechanisms; CEM's, listed companies.

* Antonija Zubović, Ph.D., Assistant Professor, University of Rijeka, Faculty of Law; azubovic@ pravri.hr.

** Edita Čulinović-Herc, Ph.D., Full professor, University of Rijeka, Faculty of Law; edita@ pravri.hr. 
Zussamenfassung

\section{PYRAMIDENSTRUKTUREN UND WECHSELSEITIG BETEILIGTE UNTERNEHMEN ALS EINE FORM DER ABWEICHUNG VOM GRUNDSATZ, EINE AKTIE - EINE STIMME*6}

In Aktiengesellschaften werden sehr oft Aktien mit ungleichen Stimmrechten, Pyramidenstrukturen und andere Mechanismen der Stärkung von Kontrolle benutzt, die eine Abweichung vom Verhältnismäßigkeitsgrundsatz darstellen. Die zur Stärkung und/oder Aufrechterhaltung der Kontrolle eingerichteten Mechanismen, von denen die Pyramidenstrukturen am meisten benutzt werden, sind relevant für die Situationen, in denen es zur Änderung der Kontrolle (Übernahme) über die börsennotierte Gesellschaft kommt. Nach der Darstellung der Taxonomie von den zur Stärkung der Kontrolle eingerichteten Mechanismen legt der Beitrag besonderen Wert gerade auf die am Kapitalmarkt entstandenen Abweichungen vom Verhältnismäßigkeitsgrundsatz, und zwar auf die Pyramidenstrukturen und wechselseitig beteiligte Unternehmen. Vor deren Analyse werden die Auswirkungen dieser Abweichungen auf das Benehmen der Aktionäre und Vorstandsmitglieder in börsennotierten Gesellschaften geprüft, welche bei der freiwilligen oder feindlichen Übernahme entstehen, aber auch in Szenarien, wo es keine Übernahmen gibt. Dabei legt man Wert darauf, ob es sich um einen Streubesitz oder konzentrierten Besitz handelt. Die für die Stärkung der Kontrolle relevanten empirischen Daten aus manchen europäischen Staaten werden auch dargestellt. Im letzten Teil des Beitrags werden die Methoden der Stimmrechtsberechnung bei Pyramidenstrukturen und wechselseitig beteiligten Unternehmen dargestellt, wonach abschließende Bemerkungen folgen.

Schlüsselwörter: Pyramidenstrukturen; wechselseitig beteiligte Unternehmen; Abweichung vom Verhältnismäßigkeitsgrundsatz; börsennotierte Aktiengesellschaften

Riassunto

\section{STRUTTURE PIRAMIDALI E SOCIETÀ CON PARTECIPAZIONI RECIPROCHE QUALE ESEMPIO DI ECCEZIONE RISPETTO AL PRINCIPIO „UNA AZIONE - UN VOTO“}

Nelle società commerciali alcune volte vengono utilizzate azioni che conferiscono un diritto al voto diseguale, strutture piramidali ed altri meccanismi di aumento del 
controllo, che rappresentano delle eccezioni rispetto al principio di proporzionalità. Tali impostati meccanismi di rafforzamento e/o detenzione del controllo, tra i quali primeggia l'utilizzo delle strutture piramidali, sono rilevanti per le situazioni nelle quali si verifichi un cambiamento nel controllo delle società quotate nei casi di offerte pubbliche d'acquisto. Nel lavoro, dopo l'illustrazione della tassonomia dei meccanismi di aumento del controllo, particolare attenzione viene diretta proprio verso quelle eccezioni rispetto al principio di proporzionalità che sorgano sul mercato dei capitali. Si tratta delle strutture piramidali e delle società con partecipazioni reciproche. Prima della loro analisi, ci si interroga circa i loro effetti sul comportamento dei soggetti interni alla corporate governance delle società quotate, ai quali si giunge in occasione di una offerta pubblica di acquisto amichevole o ostile, ma anche nello scenario in cui l'offerta pubblica di acquisto non avvenga, tenendo conto se si tratti di una società che abbia una struttura azionaria dispersiva o concentrata. Altresì si espongono ed esaminano gli indicatori empirici comprovanti gli strumenti di controllo rafforzato in alcuni ordinamenti europei. Nella parte conclusiva del lavoro si analizzano in particolare modo i metodi di calcolo della forza dei voti nelle strutture piramidali e nelle società con partecipazioni reciproche, esponendo alla fine delle considerazioni conclusive.

Parole chiave: strutture piramidali; società con partecipazioni reciproche; eccezione rispetto al principio di proporzionalità; offerta pubblica di acquisto; società per azioni quotate. 
